\title{
The role of infections and leukocytes in male infertility
}

\author{
Ralf Henkel $^{1,2}$ (i) | Ugochukwu Offor ${ }^{3}$ | David Fisher ${ }^{1}$
}

\author{
${ }^{1}$ Department of Medical Bioscience, Faculty \\ of Natural Science, University of Western \\ Cape, Bellville, South Africa \\ ${ }^{2}$ American Center for Reproductive \\ Medicine, Cleveland Clinic, Cleveland, $\mathrm{OH}$, \\ USA \\ ${ }^{3}$ Department of Pre-Clinical Sciences, \\ Faculty of Health Sciences, University of \\ Limpopo, Polokwane, South Africa

\section{Correspondence} \\ Ralf Henkel, Department of Medical \\ Bioscience, Faculty of Natural Science, \\ University of Western Cape, Bellville, South \\ Africa \\ Email: rhenkel@uwc.ac.za
}

\begin{abstract}
Declining birth rates are one of the problems facing society today. Male counterparts are responsible for about half of the infertility cases, and genitourinary tract infections may play a contributing role in approximately $15 \%$ of male infertility cases. Leukocytospermia is an established indicator of infection in the male urogenital tract, although other microorganisms such as bacteria and virus may also be contributors to the etiology of male infertility. The pathophysiology of these infectious agents may be initiated by a local inflammatory reaction resulting in an increase in reactive oxygen species (ROS). This results in testicular injury, thereby affecting sperm morphology, sperm motility, sperm viability and elevation of the seminal leukocyte as a result of the genital tract infection. The infectious and inflammatory changes can result in male infertility. It is proposed that high concentrations of seminal leukocyte and infectious agents may affect sperm function resulting in clumping of motile spermatozoa, decreasing acrosomal functionality and also causing alterations in sperm morphology. However, the literature has poorly clarified the role of infection in male infertility, provoking further debate and research on this topic.
\end{abstract}

\section{KEYWORDS}

bacterial infections, leukocytospermia, male infertility, reactive oxygen species

\section{1 | INTRODUCTION}

Infertility is a challenging health issue that affects approximately $15 \%$ of couples who are at their reproductive age desiring to have children. This condition is defined by the inability to achieve a pregnancy after at least 1 year of well-timed, unprotected sexual intercourse between consenting partners who wish to have children or failure of therapeutic donor insemination (Irvine, 1998; Lackner et al., 2006). It is a highly prevalent disease worldwide, and approximately $50 \%$ of the infertility cases are attributed to the male due to numerous andrological problems that affect the male genital tract such as cryptorchidism, varicocele, hormonal disorders, ejaculatory dysfunction and infectious diseases that are categorized as male genital tract infection (MGTI) (Agarwal, Mulgund, Hamada, \& Chyatte, 2015; Kumar \& Singh, 2015).

The literature reports that about $15 \%$ of the male infertility cases are linked to male genital tract infections (MGTIs), which would cause an abnormal increase in leukocyte counts in the human ejaculate
(Pellati et al., 2008; Sandoval, Raburn, \& Muasher, 2013). The elevation of seminal leukocyte counts, a condition referred to as 'leukocytospermia', is defined by the World Health Organization (WHO) as the presence of more than $1 \times 10^{6}$ leukocytes $/ \mathrm{ml}$ in the ejaculate (WHO, 2010). Leukocytospermia may indicate an obstruction or infection of the genitourinary tract, and the likely consequence can negatively affect sperm function by causing acrosomal damage, midpiece and tail defects (Aziz, Agarwal, Lewis-Jones, Sharma, \& Thomas, 2004; Djordjevic, Lalic, Vukovic, Nale, \& Micic, 2018; Erenpreiss, Hlevicka, Zalkalns, \& Erenpreisa, 2002; Kaleli, Öçer, Irez, Budak, \& Aksu, 2000).

Previous reports estimate that about $30 \%$ to $50 \%$ of male infertility patients are idiopathic (Keck, Gerber-Schäfer, Clad, Wilhelm, \& Breckwoldt, 1998; Krausz, 2011). Infertile couples experience many emotions, including depression, anger and shame, and they are sometimes being mocked, embarrassed and even pressured by peers, friends and parents, particularly in societies where there are high expectations for bearing children after marriage (Wright 
et al., 1991). The role of MGTI and their relevance to male infertility continues to be debated, as the mechanisms by which microorganisms and leukocytes contribute to the problem remain controversial. This review presents and considers the role of infections and leukocytes in male infertility and their implications in the development of reproductive disorders.

\section{1 | Prevalence of infection-associated male infertility}

In some developed countries in North America, Australia, and Central and Eastern Europe, literature reports an estimate of approximately $4.5 \%-6 \%, 8 \%-9 \%$ and $8 \%-12 \%$, respectively, of infertile males (Agarwal et al., 2015). In developing countries, more than $25 \%$ of married men are diagnosed with primary or secondary infertility of at least 5 years' duration (Rutstein \& Shah, 2004). The majority of infertility problems in the developing countries are secondary. SubSaharan Africa has the highest prevalence of male infertility within the developing countries (Agarwal et al., 2015). This may be due to lifestyle issues such as smoking, work-related exposure, diet or other diseases linked to sexually transmitted infections (STIs) (Lunenfeld, Van Steirteghem, \& Foundation, 2004). It is suggested that the excessive cost of most infertility treatments and assisted reproductive techniques (ARTs) could represent to a significant barrier for accessing treatment in these developing countries (Lunenfeld et al., 2004).

Following idiopathic infertility (28.4\%) and varicocele (18.1\%), MGTIs are the third most common causes of male infertility with a prevalence of $11.6 \%$ (Nieschlag \& Behre, 1997), while other studies report a prevalence of MGTI between $35 \%$ and $45 \%$ (Bayasgalan et al., 2004; Henkel et al., 2007). These infections are mainly caused by sexually transmitted pathogens such as Chlamydia trachomatis, Escherichia coli and Neisseria gonorrhea, and as a result, an excessive build-up of seminal leukocytes within the male genital tract (MGT) ensues. These pathogens and their mediators may then cause irreversible damage, especially to the testis and epididymis (Schuppe et al., 2017). On the other hand, MGTI can be seen as potentially correctable cause of male infertility as they can be treated with antibiotics and anti-inflammatories to relieve the consequences of the infection, and obstruction of the excurrent genital ducts (Weidner, Krause, \& Ludwig, 1999).

\section{2 | Deterioration of spermatogenesis and sperm function}

Spermatogenesis is a highly specialised biological process, which depends on a precisely controlled cascade of cellular differentiation and proliferation. It begins with a cell division of diploid spermatogonial stem cells and continues with sequential cell divisions of spermatogonia and meiosis of spermatocytes to form round spermatids and finally, morphological differentiation of these cells into matures spermatozoa (Shukla, Mahdi, \& Rajender, 2012). Infections

\section{Potential areas of research}

- Investigation of the effectiveness of an adjuvant therapy with antioxidants to alleviate the detrimental effect of ROS

- Investigation of the physiological role of cytokines in seminal plasma

- Investigation of the role and clinical value of leukocytospermia

or inflammatory processes in the male genital tract can alter the process of spermatogenesis, and this can lead to deterioration in the blood-testis barrier and significant formation of sperm antibodies which can be detected in serum and seminal plasma (Fijak et al., 2018). Sperm antibodies in semen may adversely affect sperm function and impair sperm motility and fertilization ability (Fijak et al., 2018). In turn, impaired spermatogenesis and poor sperm viability can result in higher leukocyte counts which then phagocytose and thereby eliminate the defective spermatozoa (Barratt, Bolton, \& Cooke, 1990; Domes et al., 2012). The presence of bacteria and the recruitment of leukocytes in the male genital tract can affect male fertility through multiple mechanisms such as direct cellular interactions, agglutinations, the release of reactive oxygen species (ROS) and cytokines not only leading to deterioration of spermatogenesis, and genital tract dysfunction, but also to deteriorated sperm function and integrity (Domes et al., 2012).

ROS can cause lipid peroxidation of the sperm plasma membrane, which has an extraordinary high amount of polyunsaturated fatty acids (Parks \& Lynch, 1992) and is therefore specifically prone to oxidative damage. In addition, ROS have been linked to increase in sperm DNA fragmentation (SDF) (Alahmar, 2019; Lopes, Jurisicova, Sun, \& Casper, 1998; Mahfouz et al., 2010). Considering that the oxidative damage can occur in testis and epididymis as well as in the ejaculate, DNA-damaged spermatozoa can be found in all of these sites (González-Marín, Gosálvez, \& Roy, 2012). Even if the male accessory sex glands are infected, sperm function including the DNA can be affected by the influence of ROS produced by activated leukocytes as these trigger apoptosis in mature human spermatozoa (Sasikumar, Dakshayani, \& Sarasa, 2013). Bacteria can also directly induce apoptosis in spermatozoa (Villegas, Schulz, Soto, \& Sanchez, 2005). Sperm DNA damage may affect early post-implantation embryo development and thus decrease the fertility and pregnancy rate (Borini et al., 2006). A recent meta-analysis indicated that men whose ejaculates have a percentage of more than 20\% DNAfragmented spermatozoa have a high probability of being infertile (Santi, Spaggiari, \& Simoni, 2018).

An orchitis, that is an inflammatory lesion of the testis, can lead to tubular damage (Weidner et al., 2002), spermatogenic arrest and testicular atrophy, and can be the cause of intratesticular obstruction in approximately 15\% of the cases (Diemer \& Desjardins, 1999; Weidner et al., 2002). In a mouse model, distinct cellular and 
molecular indications of testicular inflammation with disruption of spermatogenesis can be seen (Klein et al., 2020). It also appears that various immunopathological alterations in the testis play a major role leading to irreversible damage of spermatogenesis (Schuppe \& Meinhardt, 2005; Schuppe et al., 2008, 2010).

\section{2 | SEMINAL LEUKOCYTES}

Most of the seminal leukocytes derive from the epididymis (Wolff, 1995). The appearance of leukocytes in the male reproductive tract and ejaculate is common (el-Demiry, 1987) as they play an important role in immunosurveillance (Kiessling, Lamparelli, Yin, Seibel, \& Eyre, 1995). Yet, their role is controversially discussed. Some authors have claimed that seminal leukocytes may not be just a response to infection, but rather act to scavenge abnormal germ cells and would play some kind of positive role in surveillance and phagocytosing of abnormal and dead spermatozoa (Jung et al., 2016; Kaleli et al., 2000). Other studies, however, paint a different picture by pointing out leukocytes as major contributors of ROS production in semen (Plante, de Lamirande, \& Gagnon, 1994; Pratap, Hottigoudar, Nichanahalli, Rajendran, \& Bheemanathi, 2019; Sharma, Pasqualotto, Nelson, \& Agarwal, 2001).

According to the WHO guidelines (WHO, 2010), the seminal leukocyte concentration should not exceed $1 \times 10^{6} / \mathrm{ml}$. Leukocyte concentrations higher than this cut-off value are regarded as leukocytospermia, a poorly defined and understood condition (Brunner, Demeter, \& Sindhwani, 2019). Leukocytospermia-induced sperm damage is a likely result of the high levels of leukocyte-derived ROS and inflammatory mediators (Agarwal, Mulgund, et al., 2014; Aitken \& West, 1990; Henkel et al., 2005; Sharma et al., 2001). Due to their exceptionally high content of polyunsaturated fatty acids in their plasma membrane and cytoplasm (Parks \& Lynch, 1992), spermatozoa are very susceptible to ROS and oxidative stress (Henkel, 2011). The excessive production of ROS has frequently been implicated as the mechanism by which pathogens and leukocytes are causing damage to male germ cells by triggering lipid peroxidation and damaging mitochondrial activity (Aitken, 2017). The sequence of events of this damage to spermatozoa involves lipid peroxidation, loss of membrane integrity, reduced motility, high incidence of DNA strand breaks and apoptosis (Henkel \& Schill, 1998; Sanocka-Maciejewska, Ciupińska, \& Kurpisz, 2005). Interestingly, these detrimental effects are obvious not only at the high lower reference value of $1 \times 10^{6}$ leukocytes $/ \mathrm{ml}$ as recommended by the World Health Organization (WHO, 2010), but also at leukocyte concentrations of as low as $0.1 \times 10^{6}$ leukocytes/ml (Agarwal, Mulgund, et al., 2014; Henkel et al., 2005).

\section{1 | Leukocyte subpopulations in semen}

The appearance of leukocytes in an ejaculate is normal and, although infertile men generally have higher seminal leukocyte counts, apparently independent from the fertility status of a man (Wolff, 1995). The pre-dominant type of leukocyte in human ejaculates is granulocytes with $50 \%-60 \%$, followed by $20 \%-30 \%$ macrophages and 2\%-5\% T lymphocytes (Wolff, 1995). Occasionally, semen samples are dominated by macrophages or T lymphocytes; the reasons for this are not clear. When correlating leukocyte subpopulation numbers with specific alterations of semen quality, high numbers of T-lymphocytes were associated with reduced sperm velocity (Wolff, 1995). This might be an effect of the T-cell cytokine interferon- $\gamma$, which has been reported to inhibit sperm motility (Fedder \& Ellermann-Eriksen, 1995). In general, it is very difficult to identify effects produced by a specific leukocyte type because there is always a mixture of different leukocyte populations in semen (Wolff, 1995).

Numerous studies indicate leukocytospermia as a significant contributor to male infertility as this condition leads to decreasing sperm motility and increasing sperm DNA damage and thereby negatively affect sperm fertilizing ability (Fariello et al., 2009; Moubasher et al., 2018; Saleh et al., 2002). The incidence of pathological leukocytospermia in infertile men ranges from $2 \%$ to $35 \%$ (Barratt et al., 1990; Kung, Ho, \& Wang, 1993) with usually reported averages between 10\% and 20\% (Lackner, Agarwal, Mahfouz, Du Plessis, \& Schatzl, 2010; Zorn, Virant-Klun, \& Meden-Vrtovec, 2000). Leukocytospermia causes an increase in ROS and pro-inflammatory cytokines, especially IL-8 and IL-6, for which higher seminal concentrations have been shown in men with genital tract inflammation (Aghazarian, Stancik, Pflüger, \& Lackner, 2013; Lotti \& Maggi, 2013; Saleh et al., 2002). Hence, elevated seminal leukocyte concentrations may reflect a genital tract infection or result from a secondary immunological response. In addition to genital tract infections, smoking, consumption of alcohol and marijuana may also increase seminal leukocyte concentrations (Close, Roberts, \& Berger, 1990; Pasqualotto et al., 2008).

Leukocytospermia is associated with significantly lower progressive motility as compared to non-leukocytospermic samples (Lackner et al., 2010; Pratap et al., 2019). This deterioration of sperm motility is a likely result of the high levels of ROS and inflammatory mediators that are produced by leukocytes (Agarwal, Virk, Ong, \& Du Plessis, 2014; Aitken, Smith, Jobling, Baker, \& De luliis, 2014; Henkel et al., 2005; Saleh et al., 2002). Elevated levels of ROS can trigger apoptosis in mature human spermatozoa and thereby reduce sperm fertilizing capacity (Agarwal, Virk, et al., 2014; Aitken et al., 2014; Saleh et al., 2002). The oxidative stress caused by excessively high ROS levels can also cause lipid peroxidation of the sperm plasma membrane (Aitken, Clarkson, \& Fishel, 1989; Cosci, Moretti, \& Collodel, 2008; Twigg, Fulton, Gomez, Irvine, \& Aitken, 1998) and has been linked to SDF and an inhibition of mitochondrial activity, which could interfere with nucleic acid synthesis, leading to chromatin damage (Pratap et al., 2019) and finally impairing tail motion (Tremellen, 2008).

On the other hand, the clinical finding of leukocytospermia is controversially discussed with different recommendations in different guidelines (Brunner et al., 2019; Sandoval et al., 2013). Despite 
TAB LE 1 Types of leukocytes, origin and numbers in fertile and infertile men (modified from Wolff, 1995)

\begin{tabular}{|c|c|c|c|c|}
\hline Leukocyte type & $\begin{array}{l}\text { Percentage in the } \\
\text { ejaculate }\end{array}$ & Main origin & Fertile men & Infertile men \\
\hline Total & & & $\begin{array}{l}170.000 \\
(8.970-20.520 .000)\end{array}$ & $\begin{array}{l}1.035 .000 \\
(43.120-104.580 .000)\end{array}$ \\
\hline Granulocytes & $50 \%-60 \%$ & $\begin{array}{l}\text { Prostate } \\
\text { Seminal vesicle }\end{array}$ & $\begin{array}{l}100.000 \\
(6.250-19.950 .000)\end{array}$ & $\begin{array}{l}537.000 \\
(31.787-91.507 .000)\end{array}$ \\
\hline T-lymphocytes & $2 \%-5 \%$ & $\begin{array}{l}\text { Epididymis } \\
\text { Rete testis }\end{array}$ & $\begin{array}{l}6.383 \\
(N D-108.666)\end{array}$ & $\begin{array}{l}31.367 \\
(N D-5.142 .250)\end{array}$ \\
\hline B-lymphocytes & Very small percentage & $\begin{array}{l}\text { Epididymis } \\
\text { Rete testis }\end{array}$ & $\begin{array}{l}\text { ND } \\
\text { (ND-25.200) }\end{array}$ & $\begin{array}{l}6.400 \\
(N D-2.904 .750)\end{array}$ \\
\hline
\end{tabular}

the significant association between the number of seminal leukocytes and seminal ROS levels, a recent study by Homa et al. could not find higher levels of sperm DNA damage in semen samples with high leukocyte counts (Homa et al., 2019). Yet, SDF was significantly higher in semen samples with oxidative stress as measured by direct chemiluminescent measurement of ROS or with the MiOXSYS system. These results indicate that seminal oxidative stress has a multifactorial dimension and leukocytes are only one contributing factor. Therefore, the current cut-off value for leukocytospermia ( $\geq 10^{6}$ leukocytes/ml) recommended by the World Health Organization has been criticised as being too high (Henkel et al., 2005; Sharma et al., 2001).

\subsection{Significance of seminal leukocytes}

The significance of leukocytes in the semen remains highly controversial, and its association with semen quality is still a matter of considerable debate in scientific reports. It is generally believed that an increase in seminal leukocytes in ejaculated semen may indicate MGTI (Esfandiari, Saleh, Abdoos, Rouzrokh, \& Nazemian, 2002; Moskovtsev, Willis, White, \& Mullen, 2007; Pentyala et al., 2007; Sandoval et al., 2013). Yet, while some studies have reported no detrimental effects of leukocytospermia, other studies have correlated seminal leukocyte elevation with impaired semen parameters, especially sperm morphology, motility and viability (Aziz et al., 2004; Lackner et al., 2010).

Adding to the confusion is another study by Kaleli et al. suggesting that seminal leukocytes at concentrations between 1 and $3 \times 10^{6} / \mathrm{ml}$ would be beneficial for sperm function due to effects of scavenging of abnormal spermatozoa (Kaleli et al., 2000). Tomlinson et al. reported that leukocytes phagocytosed abnormal spermatozoa (Tomlinson, Barratt, \& Cooke, 1993), whereas Kiessling et al. found an improvement in sperm motility in semen samples with a leukocyte concentration of $>2 \times 10^{6} / \mathrm{ml}$ (Kiessling et al., 1995). Lackner et al. suggest that the effects of leukocytes on sperm motility and normal sperm morphology would be concentration-dependent as at concentrations lower than $0.5 \times 10^{6}$ leukocytes $/ \mathrm{ml}$ a higher leukocyte concentration would be beneficial for motility and morphology.
At higher concentrations, however, these authors reported negative effects. On the other hand, a recent meta-analysis analysing 28 case-controlled retrospective studies reported that leukocytospermia was not associated with poor male fertilizing potential in assisted reproduction programs and semen quality in asymptomatic men (Castellini et al., 2020).

\section{3 | ORIGIN OF SEMINAL LEUKOCYTES}

It is thought that a major amount of leukocytes is originating from the rete testis or epididymis (Anderson et al., 1991). Apparently, these leukocytes play a major role in immunosurveillance and phagocytic clearance of abnormal spermatozoa (Tomlinson, White, Barratt, Bolton, \& Cooke, 1992). While these white blood cells are rather the macrophages, and T- and B-lymphocytes, the prostate and the seminal vesicles are rather the origin of granulocytes (Wolff, 1995). The types of leukocytes, origin and numbers in fertile and infertile men are depicted in Table 1.

\section{1 | Non-inflammatory semen}

Considering that for the chronic prostatitis/chronic pelvic pain syndrome (CP/CPPS) the diagnostic classification was not clear and many patients presenting without infection show pathogenic processes outside the prostate, a new classification system was introduced by the National Institutes of Health (Krieger, Nyberg, \& Nickel, 1999; Nickel, 1998). In this system, category III (CP/CPPS) is subdivided into category IIIA (inflammatory CPPS) and category IIIB (non-inflammatory CPPS). Weidner, Krause, et al. (1999) and Weidner and Anderson (2008) indicate that semen parameters of patients in category IIIA (inflammatory) do not significantly differ from those in category IIIB (non-inflammatory) and fertile controls. However, a study by Krieger, Ross, Deutsch, and Riley (2003) shows that the inclusion of seminal leukocytes in the diagnostic workup resulted in the detection of $95 \%$ of the inflammatory cases. Another study indicates that the inclusion of peroxidase-positive leukocytes and polymorphonuclear elastase as parameters in the 
diagnostics as levels higher than $0.113 \times 10^{6}$ leukocytes $/ \mathrm{ml}$ and more than $280 \mathrm{ng}$ elastase $/ \mathrm{ml}$ are indicative of an inflammatory process (Ludwig et al., 2003).

\section{2 | Inflammatory semen}

Several studies reported a strong association between inflammatory semen with the presence of leukocytes and male infertility (Comhaire, Mahmoud, Depuydt, Zalata, \& Christophe, 1999; La Vignera et al., 2013; Wolff et al., 1990). Semen quality can be reduced through dysregulation of spermatogenesis due to the presence of microorganisms and activation of seminal leukocytes (Comhaire et al., 1999; La Vignera et al., 2013). In turn, leukocytes release not only ROS, but also pro-inflammatory cytokines such as tumor necrosis factor- $\alpha$ (TNF- $\alpha$ ), interleukin-1 $\alpha$, interleukin-6 or interleukin-8 leading to an inflammatory response (Comhaire et al., 1999; Haidl, Haidl, Oltermann, \& Allam, 2015; Kocak, Yenisey, Dündar, Okyay, \& Serter, 2002). Evidence suggests that inflammation of the genital tract affects semen quality and can lead to deterioration of the spermatogenesis, impairment of sperm function and obstruction of the seminal tract (Azenabor, Ekun, \& Akinloye, 2015). Inflammatory conditions considerably influence the secretory function of the male accessory organs. Genital tract inflammations can affect urethra, epididymis, testicles and prostate gland (Azenabor et al., 2015).

Cytokines, especially TNF- $\alpha$ and interleukin-8, either alone or in the presence of leukocytes, can trigger sperm lipid peroxidation (Fraczek, Sanocka, Kamieniczna, \& Kurpisz, 2008; Martinez, Proverbio, \& Camejo, 2007). A recent study by Chyra-Jach et al. shows that seminal interleukin-8 levels in patients with asthenozoospermia and oligoasthenozoospermia are more than $60 \%$ higher than in the controls (Chyra-Jach et al., 2018). An in vitro study by Leisegang and Henkel indicates that cytokines such as TNF- $\alpha$, IL-1 $\beta$ and IL- 6 cause a dose-dependent decline in testosterone synthesis in TM3 Leydig cells suggesting that chronic inflammation may even directly affect steroidogenesis by direct modulation of Leydig cell function, thus compromising male fertility (Leisegang \& Henkel, 2018).

\subsection{1 | Prostatitis}

Prostatitis is an inflammation of the prostate gland with a prevalence between $4 \%$ and $11 \%$. Prostatitis is the most common urological diagnosis in younger and middle-aged men (Nickel, Downey, Hunter, \& Clark, 2001). Approximately 5\%-10\% of the diagnosed prostatitis are of bacterial origin (Brunner, Weidner, \& Schiefer, 1983). While the Gram-negative bacterium Escherichia coli is the cause of bacterial prostatitis in about $80 \%$ of the cases (Lopez-Plaza \& Bostwick, 1990; Weidner, Ludwig, Brähler, \& Schiefer, 1999), other bacterial infections that have been isolated in prostatitis cases are Gram-positive enterococci (Sharp, Takacs,
\& Powell, 2010) Chlamydia trachomatis, Ureaplasma urealyticum, Nesisseria gonorrhea, and Klebsiella species (Marconi, Pilatz, Wagenlehner, Diemer, \& Weidner, 2009).

Since patients present with multiple urogenital, perineal and perianal symptoms, prostatitis is characterized by very diverse clinical symptoms such as acute bacterial infection or chronic pelvic pain syndrome (prostatitis syndrome) (Roberts, Lieber, Bostwick, \& Jacobsen, 1997; Roberts et al., 1998) and is recognized as one cause of male infertility with the clinical presentation varying from asymptomatic inflammation to severe urological symptoms. Literature reports have shown that prostatitis is linked with decreased prostatic excretory function and has negative impact on male fertility potential affecting sperm morphology as well as sperm motility (Alshahrani, Mcgill, \& Agarwal, 2013). The National Institutes of Health proposed a classification of prostatitis syndromes in four categories (Krieger et al., 1999): acute and chronic bacterial prostatitis (categories I and II), chronic pelvic pain syndrome (CPPS) (category III) and asymptomatic inflammatory prostatitis (category IV). Men with chronic prostatitis present an episodic and relapsing condition characterized by pelvic pain, irritative voiding symptoms and effects on sexual function (McNaughton Collins, MacDonald, \& Wilt, 2000).

\subsection{2 | Epididymitis}

Epididymitis is an inflammatory condition of the epididymis in males presenting with acute unilateral or bilateral swelling of the scrotum. In young, sexually active men, the inflammation is caused in most cases by Chlamydia trachomatis or Neisseria gonorrhoeae, whereas E. coli is pre-dominantly found in older men (Ludwig, 2008; Weidner, Krause, et al., 1999). In the latter group of patients, a higher risk of urethral strictures, bladder neck obstruction or benign prostatic hyperplasia (BPH) has been reported (Chan \& Schlegel, 2002). In addition to the loss of sperm function, inflammatory obstruction of the epididymal duct has been considered as an underlying cause of persistent azoospermia or oligozoospermia (Schuppe \& Bergmann, 2013). Histopathological results of epididymitis are characterized by massive infiltration of neutrophils in the interstitial compartment and loss of adluminal compartment and thickened lamina propria in the seminiferous tubules (Schuppe \& Bergmann, 2013).

The inflammation may spread to the corresponding testes as 'epididymo-orchitis' and has consistently been associated with high rates of infertility in many clinical studies. In a report by Osegbe, many men with unilateral epididymo-orchitis had contralateral biopsies showing bilateral gonadal damage and also experienced azoospermia (Osegbe, 1991). Collective analysis indicates profound deterioration of semen quality (sperm concentration, motility, morphology) together with pronounced leukocytospermia in the acute phase of the disease (Osegbe, 1991). Due to the bacterial infection ascending to the testis, a testicular involvement with spermatogenesis being affected may occur in $60 \%$ of the cases (Ludwig, 2008). In these cases, Chlamydia trachomatis and Neisseria gonorrhoeae are etiologically responsible. 


\subsection{3 | Orchitis}

Orchitis is an inflammatory lesion of the testes that can be caused by Chlamydia trachomatis and Neisseria gonorrhea. These pathogens are the particular cause of the disease in men younger than 35 years. In contrast, in older men, Escherichia coli has been found to be the predominant trigger (Schuppe et al., 2008). Furthermore, the mumps virus affects the testicles as mumps orchitis in $20 \%-30 \%$ of the cases (Bartak, 1973) which may lead to infertility in up to $87 \%$ of the patients (Behrman, Kliegman, \& Jenson, 2004; Caseslla, Leibundgut, Lehmann, \& Gasser, 1997).

Clinically, an orchitis is associated with a pre-dominantly leukocytic exudate in the seminiferous tubules resulting in tubular damage (Schuppe \& Bergmann, 2013; Weidner et al., 2002). Affected seminiferous tubules show degeneration of the germinal epithelium and thickening of the lamina propria which may result in fibrosis of the tubules (Schuppe \& Bergmann, 2013; Schuppe et al., 2008). As a consequence of this infection, testicular atrophy with spermatogenic arrest can occur. In turn, this would then result in poor sperm quality with low sperm counts (Schuppe et al., 2008). In about $15 \%$ of the cases of azoospermia, an orchitis is the cause of an intratesticular obstruction (Weidner et al., 2002).

\subsection{4 | Urethritis}

Urethritis is an inflammation of the urethra caused by sexually transmitted pathogens such as Chlamydia trachomatis, Mycoplasma or Neisseria gonorrhoea. Neisseria gonorrhea is isolated in approximately $20 \%$ of men with urethritis (Ness, Markovic, Carlson, \& Coughlin, 1997), while in $30 \%-50 \%$ of men with non-gonococcal urethritis is caused by $C$. trachomatis and $10 \%-40 \%$ of infected cases of urethritis are associated with U. urealyticum (Ness et al., 1997). Non-sexually transmitted uropathogens such as Enterobacteriaceae and staphylococci are also triggering urethritis with an incidence between 20\% and 31\% (Ochsendorf, 2006). In addition, non-infectious urethritis can be caused by injuries, masturbation or certain medical treatments.

Symptoms of urethritis in men typically include urethral discharge, penile itching or tingling, and dysuria (Brill, 2010). In a prospective study by Osegbe, 45 men with gonococcal urethritis showed extensive seminiferous tubular necrosis and inflammatory cell infiltration. After a 2-year follow-up period, $27 \%$ of the patients were found to have persistent azoospermia, and $33 \%$ had no significant improvement in sperm density (Osegbe, 1991).

\subsection{5 | Male accessory gland infections (MAGI)}

Originally, the term 'male accessory gland infection' (MAGI) was established to attribute ejaculatory inflammatory signs to the originally affected organ which may explain why this specific term was chosen (Comhaire, Verschraegen, \& Vermeulen, 1980). It comprises the infection/inflammation of the prostate, seminal vesicles and the Cowper's glands. According to Dohle et al. (2005), however, the definition would be wider and includes epididymitis and inflammations of the excurrent duct system, thus anatomical parts of the male reproductive system that are not deemed accessory glands. However, in the light of all these organs being commonly affected and the notion by Fijak et al. (2018) that the term MAGI ignores important diagnostic aspects of infectious/non-infectious or autoimmune inflammatory conditions. Since a clear distinction between specific localized infections cannot be made (Krause, 2008), one should rather use the term 'male genital tract inflammation' (Haidl, Haidl, Allam, \& Schuppe, 2019).

Previously, the presence of one or more abnormal sperm parameters associated with general symptoms of male genital tract inflammations such as leukocytospermia, presence of bacteria and a history of urogenital tract infections/inflammations was widely accepted as parameters having diagnostic significance (Rowe, Comhaire, Hargreave, \& Mellows, 1993). However, more recently, elevated levels of polymorphonuclear granulocyte elastase ( $\geq 230 \mathrm{ng} / \mathrm{ml}$ ) and pro-inflammatory cytokines such as IL-6 and IL-8 have emerged as more promising parameters in the diagnosis and management of MAGI (Depuydt, Bosmans, Zalata, Schoonjans, \& Comhaire, 1996; Grande, Milardi, Baroni, Luca, \& Pontecorvi, 2018; Kocak et al., 2002; Schiefer \& von Graevenitz, 2006) as these parameters may significantly compromise sperm functions by directly affecting sperm function and increasing seminal ROS levels (Aitken et al., 1998; Fraczek et al., 2008; Henkel et al., 2005). Considering that the infection/inflammation is also affecting the secretory functions of the accessory glands, determination of their secretions such as citric acid, fructose, $\alpha$-glucosidase, phosphatase or zinc (Krause, 2008; Wolff, Bezold, Zebhauser, \& Meurer, 1991) can also be done to provide additional information (La Vignera et al., 2013).

\section{4 | UROGENITAL TRACT INFECTION AND LEUKOCYTOSPERMIA}

Infections in the male genital tract are discussed as a leading cause of male infertility as infections adversely affect sperm parameters (low sperm count, sperm motility, sperm morphology, etc.) and may lead to activation and accumulation of seminal leukocytes. Generally, male genital tract infections are characterized by leukocytospermia ( $\geq 10^{6}$ peroxidase-positive leukocytes $/ \mathrm{ml}$ ), elevated levels of polymorphonuclear granulocyte elastase ( $\geq 230 \mathrm{ng} / \mathrm{ml}$ ), ROS and cytokines (Depuydt et al., 1996; Kocak et al., 2002; Schiefer \& von Graevenitz, 2006). A study by Punab et al. suggests that seminal leukocyte counts correlate significantly with the number of different microbes as well as the total microbial count (Punab, Lõivukene, Kermes, \& Mändar, 2003). In addition, the increase in the leukocyte numbers is associated with the initiation of phagocytosis.

Leukocytes release pro-inflammatory cytokines IL-6 and IL-8 (Aghazarian et al., 2013; Arata de Bellabarba et al., 2000; Lackner et al., 2010; Saxena, Soni, Randhawa, \& Singh, 2019), which, in turn, 
modulate the pro- and antioxidative system activation and promote an oxidative burst with the production of ROS (La Vignera et al., 2014; Saleh et al., 2002). Yet, the role of leukocytes in semen is controversially discussed. While Kiessling et al. indicated that seminal leukocytes have rather positive effects by surveilling spermatozoa for their normal function (Kiessling et al., 1995), Lackner et al. see a rather differentiated role with lower concentrations than $0.5 \times 10^{6} / \mathrm{ml}$ having positive effects and higher concentrations negatively affecting sperm motility and morphology (Lackner et al., 2010). Contrary, Trum et al. (1998) report that leukocytosper$\mathrm{mia}\left(>10^{6} / \mathrm{ml}\right)$ is of no diagnostic value to differentiate men with genital tract infections. Arata de Bellabarba et al. (2000) point out that leukocytospermia is clearly associated with poor semen quality. On the other hand, the presence of leukocytospermia has apparently no negative effect on fertilization and pregnancy after ICSI and IMSI (Cavagna et al., 2012). Fraczek et al. (2014) concluded that seminal bacteria are negatively associated with sperm fertilization potential, thus emphasising the negative impact of bacteria and leukocytes on sperm motility and sperm membrane lipid bilayers.

The kinetics of urogenital tract infections may be characterised by different mechanisms (Fraczek \& Kurpisz, 2007). The initial steps begin with the direct effects of bacteria and leukocytes on spermatozoa followed by indirect effects of the bacteria and leukocytes on spermatozoa. Several pathogens such as Escherichia coli, Staphylococcus aureus, Ureaplasma urealyticum or Mycoplasma hominis have been show to decrease various sperm functions such as count, motility or mitochondrial membrane potential (Fraczek et al., 2012; Isaiah, Nche, Nwagu, \& Nnanna, 2011; Köhn et al., 1998; Mazzoli et al., 2010; Mehta, Sridhar, Kumar, \& Kumar, 2002; Rybar et al., 2012; Sanocka-Maciejewska et al., 2005). This direct interaction of bacteria with spermatozoa appears to be a consequence of adhesion of the pathogens to the sperm membrane, which contains a high amount of glycoproteins, and is therefore susceptible to bacteria binding in receptor-specific interactions resulting in agglutinations (Kaur \& Prabha, 2014; Monga \& Roberts, 1994).

Indirect effects of bacteria and leukocytes on spermatozoa include the actions of ROS, the induction of apoptosis or necrosis and immune reactions, which include the effects of pro-inflammatory cytokines. Several studies show a significant positive relationship between the number of leukocytes and the seminal ROS levels (Esfandiari, Sharma, Saleh, Thomas, \& Agarwal, 2003; Henkel et al., 2005; Henkel \& Schill, 1998; Homa et al., 2019; Lobascio et al., 2015). Excessive amounts of ROS are causing oxidative stress which is known to have detrimental effects on spermatozoa as they trigger lipid peroxidation of the extremely susceptible sperm plasma membrane or directly cause sperm DNA damage (Aitken et al., 2014; Lopes et al., 1998; Mahfouz et al., 2010; Parks \& Lynch, 1992). Finally, the end products of lipid peroxidation, which are not only mutagenic and genotoxic (Luczaj \& Skrzydlewska, 2003), but also cytotoxic, ultimately cause DNA damage by formation of DNA adducts (Esterbauer, 1993). Furthermore, these end products such as malondialdehyde or 4-hydroxy-nonenal may persist in the semen for a prolonged period of time after the infectious agent has been eradicated, and may therefore further damage the male germ cells (La Vignera et al., 2014). According to Fraczek et al. (2016), bacteria mainly cause mitochondrial-dependent apoptotic cell death of spermatozoa, whereas leukocytospermia is the driving force for oxidative damage of the spermatozoa.

Another indirect effect of an infection is the induction of apoptosis. Although apoptosis in ejaculated human spermatozoa is controversially discussed, a number of reports suggest this process as one cause for male infertility (Roessner, Paasch, Kratzsch, Glander, \& Grunewald, 2012; Said et al., 2006; Zorn, Golob, Ihan, Kopitar, \& Kolbezen, 2012). During this process, mature spermatozoa externalise phosphatidylserine from the inner membrane leaflet to the outer leaflet and lose mitochondrial membrane potential (Koppers, Mitchell, Wang, Lin, \& Aitken, 2011). Consequently, the mitochondrial electron transport chain is uncoupled resulting in intracellular ROS production, which then exerts their deleterious effects on the spermatozoa (Aitken et al., 2012; Koppers et al., 2011; Treulen, Uribe, Boguen, \& Villegas, 2015). In patients with urogenital tract infections and inflammations, higher percentages of apoptotic spermatozoa have been reported (Allam et al., 2008; La Vignera, Condorelli, D'Agata, Vicari, \& Calogero, 2012).

\subsection{WHO definition}

There is controversy whether the WHO definition of leukocytospermia as more than $1 \times 10^{6}$ leukocytes $/ \mathrm{ml}$ in semen is a valid threshold (WHO, 2010). However, on the basis of the outcomes of semen quality and results of in vitro fertilization, De Geyter, De Geyter, Behre, Schneider, and Nieschlag (1994) indicated no association between leukocytospermia and fertilization in vitro. Only at leukocyte concentrations higher than $6 \times 10^{6} / \mathrm{ml}$ IVF success rates dropped. Wolff indicated that a cut-off value for leukocytes in fertile men varies from $1 \times 10^{6}$ to $2 \times 10^{6} / \mathrm{ml}$ in semen, which would indicate that the clinically relevant level for leukocytospermia could be higher than $10^{6} / \mathrm{ml}$ (Wolff, 1995). On the other hand, others consider it as a very high cut-off (Henkel et al., 2005; Punab et al., 2003; Sharma et al., 2001). In these studies, significant differences in motility, SDF, etc., were found with cut-off values as low as $0.1 \times 10^{6} / \mathrm{ml}$. Aitken and co-workers even reported significant effects in motility if Percoll-separated spermatozoa were exposed to more than $2 \times 10^{4}$ / ml (Aitken et al., 1995).

\section{2 | Pathogens causing urogenital infections}

The most prevalent pathogens in the male reproductive tract Chlamydia trachomatis, Ureaplasma urealyticum, Neisseria gonorrhea, Mycoplasma hominis, Mycoplasma genitalium or Escherichia coli. Except for Escherichia coli, which is particularly responsible for epididymo-orchitis or prostatitis in $65 \%-80 \%$ of the cases (Pellati et al., 2008), the other listed uropathogens are sexually transmitted. These microorganisms have been shown to greatly affect the 
fertilizing capacity of males due to their effects on human spermatozoa (Huwe et al., 1998; Sanocka-Maciejewska et al., 2005; Villegas, Schulz, Soto, \& Sanchez, 2005). They can cause an asymptomatic inflammation in the male urogenital tract (Sanocka-Maciejewska et al., 2005; Villegas, Schulz, Soto, \& Sanchez, 2005) or an acute inflammatory response with a flow of leukocytes into the genital tract leading to deterioration of spermatogenesis, impairment of sperm function (Skau \& Folstad, 2003) and increase the production of ROS (Villegas, Schulz, Soto, Iglesias, et al., 2005).

\subsection{1 | Chlamydia trachomatis}

According to the World Health Organization (2011), chlamydial infections are the most common sexually transmitted disease with about 101 million infections being detected annually. Since this infection is rather asymptomatic in about $50 \%$ of men and up to $80 \%$ in women, this number is rather underestimated (Gonzales et al., 2004) and even newborns are infected during delivery accounting for $25 \%-50 \%$ of conjunctivitis and $10 \%-20 \%$ of pneumonia in babies. Villegas, Pinon, Shor, and Karchmer (1991) demonstrated elementary bodies of Chlamydia trachomatis in the connective tissue in the testis and in Leydig cells. Other organs of the male reproductive tract such as the prostate (Corradi et al., 1996), epididymis and seminal vesicles (Bornman et al., 1998) were also positive for Chlamydia. Other studies showed that the lipopolysaccharides secreted by Chlamydiae can directly damage spermatozoa leading to cell death, induction of apoptosis and protein alterations (Eley, Hosseinzadeh, Hakimi, Geary, \& Pacey, 2005; Hosseinzadeh, Brewis, Pacey, Moore, \& Eley, 2000; Hosseinzadeh, Pacey, \& Eley, 2003).

This pathogen is the most important etiologic cause of non-gonococcal urethritis and acute epididymitis in men younger than 35 years (Bar-Chama \& Fisch, 1993). Kokab et al. established a significant relationship between infections with Chlamydia trachomatis and increased IL-8 levels as well as seminal leukocyte concentrations (Kokab et al., 2010). The percentage of progressively motile spermatozoa decreased in patients with Chlamydia trachomatis infections. Infection with these bacteria has significant detrimental effects, not only on sperm parameters in general, but also specifically on DNA integrity (Zeyad, Amor, \& Hammadeh, 2017).

\subsection{2 | Mycoplasmataceae}

Mycoplasmataceae is a family of bacteria which comprises Mycoplasma and Ureaplasma. Mycoplasmas are sexually transmitted bacteria causing clinical presentation such as cervicitis, urethritis, endometritis (Cohen et al., 2002; Sethi, Singh, Samanta, \& Sharma, 2012), damages to the acrosomal membrane (Köhn et al., 1998) or can damage the sperm DNA via the secondary effects of the infection (Gallegos et al., 2008).
Ureaplasma urealyticum

Ureaplasma is one genus of the bacterial family of Mycoplasmataceae. In this genus, Ureaplasma urealyticum and Ureaplasma parvum are the most important pathogens of the Ureaplasma genus with andrological relevance. Ureaplasma urealyticum is frequently found in the urethra of sexually active men (Purvis \& Christiansen, 1993) and causes symptomatic and asymptomatic non-gonococcal urethritis in up to $25 \%$ of the cases (Moskowitz \& Mellinger, 1992), as well as pelvic inflammatory disease or infertility (Schiefer, 1998; Weidner, Ludwig, et al., 1999). Apart from causing higher seminal viscosity (Wang et al., 2006), an infection with Ureaplasma urealyticum has also effects on the male germ cells by negatively affecting sperm morphology (Zhang et al., 2011) as well as concentration, motility and vitality (Calogero, La Vignera, Condorelli, D’Agata, \& Vicari, 2011; Köhn et al., 1998).

Although the role of Ureaplasma species was controversially discussed in the past (Kjaergaard et al., 1997; Potts, Sharma, et al., 2000), there is mounting evidence that these pathogens, particularly Ureaplasma urealyticum, play a significant role in genital tract infections under specific conditions (Beeton, Payne, \& Jones, 2019). It appears that in infertile men, $U$. urealyticum is more prevalent than U. parvum (Zeighami, Peerayeh, Yazdi, \& Sorouri, 2009; Zhang et al., 2014; Zhou, Ma, Shi, \& Liu, 2018) indicating that U. urealyticum has a clearly higher causative role in infertile men. Nevertheless, $U$. urealyticum is also increasingly identified to cause adverse pregnancy outcomes (Capoccia, Greub, \& Baud, 2013) and both U. urealyticum and U. parvum are implicated in chorioamnionitis (Sweeney, Dando, Kallapur, \& Knox, 2017).

Mycoplasma hominis and Mycoplasma genitalium

Mycoplasma is another genus of the bacterial family of Mycoplasmataceae. These bacteria lack a cell wall. Andrologically important mycoplasmas are Mycoplasma hominis and Mycoplasma genitalium, both of which are causing urogenital infections (AndradeRocha, 2003; Deguchi \& Maeda, 2002) and have been recognised as a common sexually transmitted disease (Yoshida, Maeda, Deguchi, \& Ishiko, 2002). Infection incidences for Mycoplasma hominis and Mycoplasma genitalium are reported with $10.8 \%$ and $5 \%$, respectively (Gdoura et al., 2007). Both pathogens are reported to affect the onset of pregnancy as they can attach and penetrate the sperm plasma membrane (Diaz-Garcia, Herrera-Mendoza, Giono-Cerezo, \& Guerra-Infante, 2006; Taylor-Robinson, 2002; Vallely et al., 2018). Spermatozoa from samples tested positive for Mycoplasma DNA show a lower penetration rate into zona-free hamster oocytes as compared with controls (Kalugdan, Chan, Seraj, \& King, 1996). A study by Ahmadi, Mirsalehian, Sadighi Gilani, Bahador, and Talebi (2017) shows that even an asymptomatic infection with Mycoplasma hominis significantly affects semen parameters including sperm count, motility, morphology, seminal ROS production and total antioxidant capacity. In contrast, the ejaculatory volume and $\mathrm{pH}$ were not negatively affected. After antibiotic treatment with doxycycline, all seminal parameters improved significantly. 


\subsection{3 | Neisseria gonorrhoeae}

Neisseria gonorrhoeae is a Gram-negative diplococcus bacterium, which equally infects men and women at reproductive age, causing gonorrhoea (Edwards \& Apicella, 2004) and is manifesting with urethritis, cervicitis and/or salpingitis (Da Ros \& da Silva Schmitt, 2008). In men, it can also lead to prostatitis, epididymo-orchitis and infertility due to testicular damage or ductal obstruction (Bar-Chama \& Fisch, 1993). The attachment of these bacteria to other cells including spermatozoa, where they may bind to an asialoglycoprotein receptor that binds lipopolysaccharides (Harvey et al., 2000), is mediated by pili as T1 gonococci to the cell membrane (Gomez, Stenback, James, Criswell, \& Williams, 1979; Krause, 2008). In addition, T4 gonococci may also directly attach to spermatozoa (Stohl et al., 2012). In turn, this will attract leukocytes to the infection site and consequently increase seminal ROS levels, thereby damaging the male germ cells (Ochsendorf, 1999; Potts, Notarianni, \& Jefferies, 2000).

Usually, the infection is symptomatic with severe dysuria and a purulent urethral discharge. Gonorrhoea is the second most frequently reported sexually transmitted disease in the United States with 583,405 reported cases in 2018 (Centers for Disease Control and Prevention, 2019). A recent meta-analysis of 147 studies from 56 countries indicates a global prevalence of $2.2 \%$ with Africa having the highest prevalence of $5.0 \%$ and the South-East Asia region with one out of 843 patients in 8 studies tested positive (0.1\%) lowest (Chemaitelly et al., 2020).

\subsubsection{Escherichia coli}

Escherichia coli is a Gram-negative bacterium causing most infections in the urogenital tract and male accessory gland (Weidner, Ludwig, et al., 1999). Several studies have described direct detrimental effects of Escherichia coli on sperm motility (Diemer, Huwe, et al., 2000), acrosome reaction (Köhn et al., 1998) and fertilization potential (Diemer et al., 2003; Huwe et al., 1998; Villegas, Boguen, \& Uribe, 2017). The detrimental effects on motility and acrosome reaction might be due to the direct interaction of the pathogen by means of pili (Diemer et al., 2003; Sanchez, Villagran, Concha, \& Cornejo, 1989) with the sperm plasma membrane leading to morphological alterations (Diemer, Huwe, et al., 2000). This decrease in sperm motility has been attributed to an agglutinating effect on spermatozoa (Kaur \& Prabha, 2014; Liu et al., 2002). Sperm agglutination can be caused by bacterial type 1 and $P$ fimbriae; particularly, the type 1 fimbriae of Escherichia coli cause a pattern of head-head type agglutination because they bind mannose residues in the head region of spermatozoa (Monga \& Roberts, 1994).

According to Villegas et al., Escherichia coli is even able to induce early apoptotic events by activating several caspases and proteases responsible for mitochondrial changes and SDF (Fraczek \& Kurpisz, 2015; Villegas, Schulz, Soto, Iglesias, et al., 2005). This leads to a breakdown of the sperm mitochondrial membrane potential, thus causing degeneration of ATP production. Moreover, soluble products of Escherichia coli reportedly decrease sperm motility by causing defects in the sperm cell's mitochondrial function (Barbonetti et al., 2013; Schulz, Sánchez, Soto, Risopatrón, \& Villegas, 2010).

There are several mechanisms by which Escherichia coli is detrimental to spermatozoa. One of them is by mediating seminal leukocyte activation (Villegas et al., 2017). Leukocytes release pro-inflammatory cytokines (IL-6 and IL-8), which trigger a decrease in sperm motility (Diemer, Ludwig, Huwe, Hales, \& Weidner, 2000; Villegas et al., 2017). This damaging effect seems to be mediated by polymorphonuclear (PMN) leukocytes. In addition, ROS released after bacteria-induced activation also play a major role in the deterioration of sperm quality. Specifically, Escherichia coli is able to induce a higher ROS production than other bacteria (Moretti et al., 2009; Villegas et al., 2017).

\subsection{5 | Viruses}

A growing body of evidence indicates that a number of viruses can infect all parts of the male genital tract and thereby negatively affect the male fertility potential. Among these viruses are the mumps virus (orchitis), human immunodeficiency virus-1 (orchitis and prostatitis), Coxsackie virus (epididymitis), cytomegalovirus (vesiculitis), human papillomavirus and herpes simplex virus (prostatitis) (Dejucq $\&$ Jegou, 2001). These infections lead to male infertility by increasing seminal leukocyte concentrations (Karamolahi et al., 2019; Umapathy, Simbini, Chipata, \& Mbizvo, 2001; Weinberg, Sar-Shalom Nahshon, Feferkorn, \& Bornstein, 2020; Wu et al., 2019). The latter virus can infect the testes and male sex accessory glands (Le Tortorec \& Dejucq-Rainsford, 2010). Sexually transmitted viruses, among them human papillomavirus, hepatitis B virus, herpes simplex virus or Epstein-Barr virus, have been detected in semen (Dejucq \& Jegou, 2001; Kapranos, Petrakou, Anastasiadou, \& Kotronias, 2003).

There are two different modes by which viral infections can enter the male urogenital tract system: ascent through the urethra or hematogenously (Keck et al., 1998). These effects can be exerted either by direct toxic effects on the cells or indirectly via local inflammatory or immunological reactions (Keck et al., 1998). Due to the highly restrictive nature of the blood-testis barrier, the pathogens can possibly survive for extended periods by escaping immunosurveillance if they penetrate into the seminiferous tubules (Anderson \& Politch, 1996). This is an aspect that can be of particular importance for assisted reproduction as this requires appropriate andrological diagnosis and management of the patient as well as proper handling of semen samples by the embryologist, because semen is a vector to propagate viruses. In addition, HIV viruses can bind to and penetrate into spermatozoa via a CD-4-independent receptor and/or the HIV co-receptor CCR5 (Bandivdekar, Velhal, \& Raghavan, 2003; Muciaccia, Padula, Gandini, Lenzi, \& Stefanini, 2005). Viruses originating from the testes or the epididymides can also attach to the male germ cells (Le Tortorec \& Dejucq-Rainsford, 2010; Muciaccia et al., 2007). 
Since angiotensin-converting enzyme-2 is present on Leydig and Sertoli cells and the fact that SARS-CoV-2, the virus that causes COVID-19, utilises this enzyme as a receptor to enter human cells, it is plausible that COVID-19 could affect testicular function and therefore male fertility (Illiano, Trama, \& Costantini, 2020).

\section{5 | MEDIATORS AND MECHANISMS OF INFLAMMATORY DAMAGE}

\section{$5.1 \mid$ ROS}

In urogenital tract infections, bacteria can be observed in the semen shortly after their entry into the male genital tract. In the second phase of the infection, leukocytes are attracted to combat the infection. While bacteria can directly interact with the spermatozoa and trigger the mitochondrial pathway of apoptosis (Barbonetti et al., 2013; Fraczek et al., 2012; Schulz et al., 2010), macrophages release cytokines and ROS as pro-inflammatory mediators of the infection (Fraczek \& Kurpisz, 2015; Shahed \& Shoskes, 2000; Zhou, Xiao, Zheng, Dong, \& Zhang, 2006). Thereby, the pathogens are triggering the ROS release by stimulating glucose-6-phosphate dehydrogenase which is leading to the production of large amounts of NADPH providing the electrons to reduce oxygen to superoxide anion and other ROS. Consequently, these ROS trigger the activation of chemokines CXCL5, CXCL8, IL-6 and IL-8 (Comhaire, Bosmans, Ombelet, Punjabi, \& Schoonjans, 1994), which will trigger further ROS production resulting in seminal oxidative stress and infertility (Agarwal, Saleh, \& Bedaiwy, 2003).

\section{2 | Cytokines}

Since the testis, specifically the adluminal compartment, is an immune-privileged organ (Head, Neaves, \& Billingham, 1983), Sertoli, Leydig and peritubular cells as well as testicular macrophages and testicular somatic cells are secreting immunoregulatory and immunosuppressive factors (Gao et al., 2016; Kaur, Thompson, \& Dufour, 2014). An immunosuppressive phenotype of macrophages populating the testes produces CD163 and the anti-inflammatory cytokine IL-10 (Wang et al., 2017). In case of a testicular infection, secretion of pro-inflammatory cytokines such as TNF- $\alpha$, IL-1 or IL-6 is reduced, while secretion of anti-inflammatory IL-10 is increased (Bhushan et al., 2011, 2015; Zhao, Guo, Wu, Xiong, \& Zhou, 2008). In addition, Sertoli cells also secrete anti-inflammatory factors such as activin A, which appear necessary to compensate an excessive immune response (Hedger \& Winnall, 2012). In contrast to the testis, the epididymis has not been shown to be immune-privileged as an immune response in the epididymis or other parts of the male reproductive tract. This can be seen in the fact that the incidence of epididymitis or other genital tract infections is much higher than that of an orchitis (Hedger, 2011).
Following a bacterial infection, leukocytes infiltrate the epididymis and the interstitial space after 1 day and 3 days, respectively (Lang et al., 2013; Tanaka, Fujisawa, Arakawa, \& Kamidono, 1995). Alongside the leukocyte infiltration, an increase in pro-inflammatory cytokines can be seen (Turner, Mammen, Kavoussi, Lysiak, \& Costabile, 2011), which, in turn, triggers lipid peroxidation and further ROS production by leukocytes.

\section{3 | Proteases}

After stimulation by pathogens, leukocytes do not only release ROS and cytokines, but also release proteases such as cathepsin G, collagenase and elastase. The latter can be distinguished in a serine proteinase coming from polymorphonuclear granulocytes and a metalloproteinase from macrophages (Zorn, Vidmar, \& MedenVrtovec, 2003). Since free elastase is causing cell (Hautamaki, Kobayash, Senior, \& Shapiro, 1997) and DNA damage (Yang, Kettritz, Falk, Jennette, \& Gaido, 1996) and therefore negatively affects sperm functionality. On the other hand, Maegawa et al. (2001) and Henkel et al. (2003) did not find any negative effect of elastase on sperm motility. In seminal plasma, the enzyme is inhibited under normal conditions by $\alpha_{1}$-protease inhibitor and $\alpha_{2}$-macroglobulin (Kramer et al., 1990, 1992) and secretory leukocyte protease inhibitor is able to restore sperm motility that was affected by elastase (Moriyama et al., 1998) and could possibly be the reason why no association between the seminal elastase concentration and motility was found.

\section{6 | INDUCTION OF ANTISPERM ANTIBODIES}

Since the first reports on antisperm antibody-related male infertility by Rumke (1954) and Wilson (1954), this aspect has been investigated and controversially discussed (Francavilla \& Barbonetti, 2017). In respect to male genital tract infections, an association between genital tract infections, infertility and antisperm antibodies has repeatedly been reported (Fjällbrant \& Obrant, 1968; Witkin \& Toth, 1983). Incidences of antisperm antibodies vary between 2\% (Barbonetti et al., 2019) and 15\% (Witkin, 1988). Higher incidences are reported in patients with genital tract infections and obstructions as well as after vasectomy and cystic fibrosis (Marconi \& Weidner, 2017). It has also been shown that antisperm antibodies occur significantly more often in patients with a history of epididymitis than with testicular abnormalities (Lotti et al., 2018). This is probably due to the highly restrictive nature of the blood-testis barrier, which is only damaged in acute or chronic testicular infections or inflammations with testicular immune dysregulation. In cases of antisperm antibodies occurring naturally, the cause remains idiopathic.

The prognostic value of the presence of antisperm antibodies is controversially discussed. Leushuis et al. (2009) report in a large study that included 1,794 couples no prognostic value of the MAR test for the chances of achieving a pregnancy. In contrast, Barbonetti et al. 
(2020) in a smaller study of 108 couples observed a significantly lower chance of live births after natural conception and intrauterine insemination if the MAR test was $100 \%$ positive. The authors therefore recommend testing for antisperm antibodies in the basic fertility workup.

\section{7 | LEUKOCYTE INFILTRATION AND ART}

Considering that leukocytes have a significant negative influence on sperm functions, the question arises whether leukocytospermic semen samples can be used for assisted reproduction. Surprisingly, the general presence of leukocytes in semen does not correlate with sperm concentration, motile sperm count and normal sperm morphology (Henkel et al., 2005). Aitken, West, and Buckingham (1994) indicated that the fertilizing potential of washed spermatozoa as assessed by acrosome reaction and the sperm-oocyte penetration test is not associated with the seminal leukocyte count. However, if leukocytes contaminated the washed sperm preparations, sperm functionality was significantly compromised. On the other hand, several studies show various techniques of assisted reproduction, namely IUI, IVF, ICSI and IMSI, and the leukocyte count does not have an influence on fertilization, implantation, pregnancy and live birth rates (Barraud-Lange, Pont, Pocate, et al., 2011; Barraud-Lange, Pont, Ziyyat, et al., 2011; Castellini et al., 2020; Cavagna et al., 2012; Ricci et al., 2015). It only appears that seminal leukocyte counts higher than $10^{6} / \mathrm{ml}$ lead to lower pregnancy outcome with an elevated rate of early pregnancy loss (Barraud-Lange, Pont, Pocate, et al., 2011; Barraud-Lange, Pont, Ziyyat, et al., 2011). The meta-analysis by Castellini et al. (2020) further indicates that these recommendations are restricted to patients asymptomatic for genital tract infections.

These studies indicate that seminal leukocytes are only detrimental to spermatozoa and the fertilization process if they are in close vicinity of the male germ cells and if the seminal antioxidant system is not overwhelmed by the respiratory burst of activated leukocytes leading to the release of high amounts of ROS and cytokines. If leukocytes are removed by suitable sperm separation techniques prior to assisted reproduction, the yielded spermatozoa are fully functional and competent to fertilize oocytes.

\section{8 | TREATMENT OF INFECTIONS}

Considering that male genital tract infections are in their majority caused by bacterial pathogens, such infections can be treated with antibiotics and anti-inflammatories and are therefore potentially correctable causes of male infertility (Weidner, Ludwig, et al., 1999). Yet, it is to be noticed that many of these pathogens are sexually transmitted. Therefore, both partners have to be treated after proper diagnosis and administration of a suitable antibiotic after semen culture (Solomon \& Henkel, 2017). Whereas guidelines for the treatment of acute bacterial epididymitis, epididymo-orchitis and specific granulomatous orchitis have been published (Weidner et al., 2002; Centers for Disease Control and Prevention, 2015), this is not the case for chronic infections and inflammations. Hence, treatment of these diseases rather relies on empirical and a small number of uncontrolled studies (Ludwig, 2008; Weidner et al., 2002). On the other hand, for viral infections such as mumps orchitis, a systemic treatment with 2 $\beta$-interferon (Pal, 2013; Yeniyol, Sorguc, Minareci, $\&$ Ayder, 2000) was used to prevent testicular atrophy.

On the other hand, lesions due to the inflammatory processes can be alleviated with an antiphlogistic therapy, with both corticosteroids and non-steroids, and have shown significant positive effects on various semen parameters (Haidl, 2002; Hendry, Stedronska, Hughes, Cameron, \& Pugh, 1979; Montag, van der Ven, $\&$ Haidl, 1999). In addition, antioxidant therapies to counteract the oxidative stress may be considered, but are still debated (Arafa et al., 2020; Haidl et al., 2019; Steiner et al., 2020; Tremellen, 2008).

\section{9 | CONCLUDING REMARKS}

Male genital tract infections are the third most common cause of male infertility. Despite the deleterious effects male genital tract infections can cause to the overall health of the patients in general, the male genital tract and spermatozoa in particular, hence on male fertility, these conditions can be rationally treated as most of these infections are due to bacterial pathogens. However, it is required that a proper andrological diagnostic with semen culture is carried out in order to avoid bacterial drug resistance. In addition, the treatment must be long enough to eradicate the infection. Moreover, it is mandatory that both partners have to be treated as otherwise continuous reinfections would occur. Since many patients suffer from asymptomatic, 'silent' infections, it is also essential that clinicians properly identify these conditions. Conversely, for patients trying to achieve pregnancy it is important to know that moderately high seminal leukocyte counts do not have a negative impact on assisted reproductive techniques, because the leukocytes are eliminated during sperm preparations. Therefore, this review aimed at providing an update on the current knowledge of pathophysiology of the most common male genital tract infections.

\section{Key points}

- Bacteria and viruses can directly interact with spermatozoa and compromise sperm functions

- As consequence of the infection, leukocytes are infiltrating the male genital tract and produce high amounts of ROS and cytokines

- Unphysiologically high levels of ROS are highly detrimental to spermatozoa

- Damages to the blood-testis barrier and much more commonly to the blood-epididymis barrier may lead to the production of antisperm antibodies

- Infections have to be treated properly

- Silent genital tract inflammations do not necessarily impact negatively on assisted reproduction 


\section{ORCID}

Ralf Henkel iD https://orcid.org/0000-0003-1128-2982

\section{REFERENCES}

Agarwal, A., Mulgund, A., Alshahrani, S., Assidi, M., Abuzenadah, A. M., Sharma, R., \& Sabanegh, E. (2014). Reactive oxygen species and sperm DNA damage in infertile men presenting with low level leukocytospermia. Reproductive Biology and Endocrinology, 12, 126.

Agarwal, A., Mulgund, A., Hamada, A., \& Chyatte, M. R. (2015). A unique view on male infertility around the globe. Reproductive Biology and Endocrinology, 13, 37.

Agarwal, A., Saleh, R. A., \& Bedaiwy, M. A. (2003). Role of reactive oxygen species in the pathophysiology of human reproduction. Fertility and Sterility, 79, 829-843.

Agarwal, A., Virk, G., Ong, C., \& Du Plessis, S. S. (2014). Effect of oxidative stress on male reproduction. The World Journal of Men's Health, 32, 1-17.

Aghazarian, A., Stancik, I., Pflüger, H., \& Lackner, J. (2013). Influence of pathogens and moderate leukocytes on seminal interleukin (IL)- 6 , IL-8, and sperm parameters. International Urology and Nephrology, 45, 359-365.

Ahmadi, M. H., Mirsalehian, A., Sadighi Gilani, M. A., Bahador, A., \& Talebi, M. (2017). Asymptomatic infection with Mycoplasma hominis negatively affects semen parameters and leads to male infertility as confirmed by improved semen parameters after antibiotic treatment. Urology, 100, 97-102.

Aitken, R. J. (2017). Reactive oxygen species as mediators of sperm capacitation and pathological damage. Molecular Reproduction and Development, 84, 1039-1052.

Aitken, R. J., Buckingham, D. W., Brindle, J., Gomez, E., Baker, H. W., \& Irvine, D. S. (1995). Analysis of sperm movement in relation to the oxidative stress created by leukocytes in washed sperm preparations and seminal plasma. Human Reproduction, 10, 2061-2071.

Aitken, R. J., Clarkson, J. S., \& Fishel, S. (1989). Generation of reactive oxygen species, lipid peroxidation, and human sperm function. Biology of Reproduction, 41, 183-197.

Aitken, R. J., Gordon, E., Harkiss, D., Twigg, J. P., Milne, P., Jennings, Z., \& Irvine, D. S. (1998). Relative impact of oxidative stress on the functional competence and genomic integrity of human spermatozoa. Biology of Reproduction, 59, 1037-1046.

Aitken, R. J., Smith, T. B., Jobling, M. S., Baker, M. A., \& De luliis, G. N. (2014). Oxidative stress and male reproductive health. Asian Journal of Andrology, 16, 31-38.

Aitken, R., \& West, K. (1990). Analysis of the relationship between reactive oxygen species production and leucocyte infiltration in fractions of human semen separated on Percoll gradients. International Journal of Andrology, 13, 433-451.

Aitken, R. J., West, K., \& Buckingham, D. (1994). Leukocytic infiltration into the human ejaculate and its association with semen quality, oxidative stress, and sperm function. Journal of Andrology, 15, 343-352.

Aitken, R. J., Whiting, S., De luliis, G. N., McClymont, S., Mitchell, L. A., \& Baker, M. A. (2012). Electrophilic aldehydes generated by sperm metabolism activate mitochondrial reactive oxygen species generation and apoptosis by targeting succinate dehydrogenase. Journal of Biological Chemistry, 287, 33048-33060.

Alahmar, A. T. (2019). Role of oxidative stress in male infertility: An updated review. Journal of Human Reproductive Sciences, 12, 4

Allam, J. P., Fronhoffs, F., Fathy, A., Novak, N., Oltermann, I., Bieber, T., .. Haidl, G. (2008). High percentage of apoptotic spermatozoa in ejaculates from men with chronic genital tract inflammation. Andrologia, 40, 329-334

Alshahrani, S., Mcgill, J., \& Agarwal, A. (2013). Prostatitis and male infertility. Journal of Reproductive Immunology, 100, 30-36.
Anderson, D. J., \& Politch, J. A. (1996). White blood cells in semen and their impact on fertility. In G. Cntola, \& K. A. Ginsburg (Eds.), Evaluation and treatment of the infertile male (pp. 263-277). Cambridge, UK: Cambridge University Press.

Anderson, D. J., Politch, J. A., Martinez, A., Van Voorhis, B. J., Padian, N. S., \& O'Brien, T. R. (1991). White blood cells and HIV-1 in semen from vasectomised seropositive men. Lancet, 338, 573-574.

Andrade-Rocha, F. T. (2003). Ureaplasma urealyticum and Mycoplasma hominis in men attending for routine semen analysis. Prevalence, incidence by age and clinical settings, influence on sperm characteristics, relationship with the leukocyte count and clinical value. Urology International, 71, 377-381.

Arafa, M., Agarwal, A., Majzoub, M., Panner Selvam, M. K., Baskaran, S., Henkel, R., \& Elbardisi, H. (2020). Efficacy of antioxidant supplementation on conventional and advanced sperm function tests in patients with idiopathic male infertility. Antioxidants (Basel), 9, E219.

Arata de Bellabarba, G., Tortolero, I., Villarroel, V., Molina, C. Z., Bellabarba, C., \& Velazquez, E. (2000). Nonsperm cells in human semen and their relationship with semen parameters. Archives of Andrology, 45, 131-136.

Azenabor, A., Ekun, A. O., \& Akinloye, O. (2015). Impact of inflammation on male reproductive tract. Journal of Reproduction \& Infertility, 16, 123-129.

Aziz, N., Agarwal, A., Lewis-Jones, I., Sharma, R. K., \& Thomas, A. J. Jr (2004). Novel associations between specific sperm morphological defects and leukocytospermia. Fertility and Sterility, 82, 621-627.

Bandivdekar, A. H., Velhal, S. M., \& Raghavan, V. P. (2003). Identification of CD4-independent HIV receptors on spermatozoa. American Journal of Reproductive Immunology, 50, 322-327.

Barbonetti, A., Castellini, C., D'Andrea, S., Cordeschi, G., Santucci, R., Francavilla, S., \& Francavilla, F. (2019). Prevalence of anti-sperm antibodies and relationship of degree of sperm auto-immunization to semen parameters and post-coital test outcome: A retrospective analysis of over 10000 men. Human Reproduction, 34, 834-841.

Barbonetti, A., Castellini, C., D'Andrea, S., Minaldi, E., Totaro, M., Francavilla, S., \& Francavilla, F. (2020). Relationship between natural and intrauterine insemination-assisted live births and the degree of sperm autoimmunisation. Human Reproduction, deaa070. https://doi. org/10.1093/humrep/deaa070. [Online ahead of print]

Barbonetti, A., Vassallo, M. R. C., Cinque, B., Filipponi, S., Mastromarino, P., Cifone, M. G., ... Francavilla, F. (2013). Soluble products of Escherichia coli induce mitochondrial dysfunction-related sperm membrane lipid peroxidation which is prevented by lactobacilli. PLoS One, 8, e83136.

Bar-Chama, N., \& Fisch, H. (1993). Infection and pyospermia in male infertility. World Journal of Urology, 11, 76-81.

Barratt, C. L., Bolton, A. E., \& Cooke, I. D. (1990). Functional significance of white blood cells in the male and female reproductive tract. Human Reproduction, 5, 639-648.

Barraud-Lange, V., Pont, J. C., Pocate, K., Kunstmann, J. M., ChalasBoissonas, C., Ducot, B., \& Wolf, J. P. (2011). Seminal leukocytes and clinical outcomes with donor sperm insemination. Fertility and Sterility, 96, 1320-1324.

Barraud-Lange, V., Pont, J. C., Ziyyat, A., Pocate, K., Sifer, C., CedrinDurnerin, I., ... Wolf, J. P. (2011). Seminal leukocytes are Good Samaritans for spermatozoa. Fertility and Sterility, 96, 1315-1319.

Bartak, V. (1973). Sperm count, morphology and motility after unilateral mumps orchitis. Journal of Reproduction and Fertility, 32, 491-494.

Bayasgalan, G., Naranbat, D., Tsedmaa, B., Tsogmaa, B., Sukhee, D., Amarjargal, O., ... Rowe, P. J. (2004). Clinical patterns and major causes of infertility in Mongolia. Journal of Obstetrics and Gynaecological Research, 30, 386-393.

Beeton, M. L., Payne, M. S., \& Jones, L. (2019). The Role of Ureaplasma spp. in the development of nongonococcal urethritis and infertility among men. Clinical and Microbiological Reviews, 32, e00137-e218. 
Behrman, R. E., Kliegman, R. M., \& Jenson, H. B. (2004). Nelson textbook of pediatrics (17th ed.). Philadelphia, PA: Saunders.

Bhushan, S., Hossain, H., Lu, Y., Geisler, A., Tchatalbachev, S., Mikulski, Z., ... Meinhardt, A. (2011). Uropathogenic E. coli induce different immune response in testicular and peritoneal macrophages: Implications for testicular immune privilege. PLoS One, 6, e28452.

Bhushan, S., Tchatalbachev, S., Lu, Y., Fröhlich, S., Fijak, M., Vijayan, V., ... Meinhardt, A. (2015). Differential activation of inflammatory pathways in testicular macrophages provides a rationale for their subdued inflammatory capacity. Journal of Immunology, 194, 5455-5464.

Borini, A., Tarozzi, N., Bizzaro, D., Bonu, M., Fava, L., Flamigni, C., \& Coticchio, G. (2006). Sperm DNA fragmentation: Paternal effect on early post-implantation embryo development in ART. Human Reproduction, 21, 2876-2881.

Bornman, M. S., Ramuthaga, T. N., Mahomed, M. F., Greeff, A. S., CreweBrown, H. H., \& Reif, S. (1998). Chlamydial infection in asymptomatic infertile men attending an andrology clinic. Archives of Andrology, 41, 203-208.

Brill, J. R. (2010). Diagnosis and treatment of urethritis in men. American Family Physician, 81, 873-878.

Brunner, H., Weidner, W., \& Schiefer, H. G. (1983). Studies on the role of Ureaplasma urealyticum and Mycoplasma hominis in prostatitis. Journal of Infectious Diseases, 147, 807-813.

Brunner, R. J., Demeter, J. H., \& Sindhwani, P. (2019). Review of guidelines for the evaluation and treatment of leukocytospermia in male infertility. World Journal of Mens Health, 37, 128-137.

Calogero, A. E., La Vignera, S., Condorelli, R. A., D'Agata, R., \& Vicari, E. (2011). Effects of male accessory gland infection on sperm parameters. In A. Zini, \& A. Agarwal (Eds.), Sperm chromatin: Biological and clinical applications in male infertility and assisted reproduction ( $\mathrm{pp}$. 375-394). Switzerland: Springer Nature.

Capoccia, R., Greub, G., \& Baud, D. (2013). Ureaplasma urealyticum, Mycoplasma hominis and adverse pregnancy outcomes. Current Opinions on Infectious Diseases, 26, 231-240.

Casella, R., Leibundgut, B., Lehmann, K., \& Gasser, T. C. (1997). Mumps orchitis: Report of a mini-epidemic. Journal of Urology, 158, 2158-2161.

Castellini, C., D'Andrea, S., Martorella, A., Minaldi, E., Necozione, S., Francavilla, F., ... Barbonetti, A. (2020). Relationship between leukocytospermia, reproductive potential after assisted reproductive technology, and sperm parameters: A systematic review and meta-analysis of case-control studies. Andrology, 8, 125-135.

Cavagna, M., Oliveira, J. B. A., Petersen, C. G., Mauri, A. L., Silva, L. F., Massaro, F. C., ... Franco, J. G. (2012). The influence of leukocytospermia on the outcomes of assisted reproductive technology. Reproductive Biology and Endocrinology, 10, 44.

Centers for Disease Control and Prevention [CDC] (2015). Sexually transmitted diseases treatment guidelines. Morbidity and Mortal Weekly Report, 64(3), 1-140. Retrieved from http://www.cdc.gov/ std/tg2015/default.htm

Centers for Disease Control and Prevention. Atlanta: U.S. Department of Health and Human Services (2019). Sexually Transmitted Disease Surveillance 2018; Centers for Disease Control and Prevention. Atlanta, GA: U.S. Department of Health and Human Services.

Chan, P. T., \& Schlegel, P. N. (2002). Inflammatory conditions of the male excurrent ductal system. Part I. Journal of Andrology, 23, 453-460.

Chemaitelly, H., Majed, A., Abu-Hijleh, F., Blondeel, K., Matsaseng, T. C., Kiarie, J., ... Abu-Raddad, L. J. (2020). Global epidemiology of Neisseria gonorrhoeae in infertile populations: Systematic review, meta-analysis and metaregression. Sexually Transmitted Infections, 18, sextrans-2020-054515. https://doi.org/10.1136/sextrans-2020054515. [Online ahead of print]

Chyra-Jach, D., Kaletka, Z., Dobrakowski, M., Machon-Grecka, A., Kasperczyk, S., Birkner, E., \& Kasperczyk, A. (2018). The associations between infertility and antioxidants, proinflammatory cytokines, and chemokines. Oxidative Medicine and Cellular Longevity, 2018, 8354747.

Close, C. E., Roberts, P. L., \& Berger, R. E. (1990). Cigarettes, alcohol and marijuana are related to pyospermia in infertile men. Journal of Urology, 144, 900-903.

Cohen, C. R., Manhart, L. E., Bukusi, E. A., Astete, S., Brunham, R. C., Holmes, K. K., ... Totten, P. A. (2002). Association between Mycoplasma genitalium and acute endometritis. Lancet, 359, 765-766.

Comhaire, F., Bosmans, E., Ombelet, W., Punjabi, U., \& Schoonjans, F. (1994). Cytokines in semen of normal men and of patients with andrological diseases. American Journal of Reproductive Immunology, 31, 99-103.

Comhaire, F., Mahmoud, A., Depuydt, C., Zalata, A., \& Christophe, A. (1999). Mechanisms and effects of male genital tract infection on sperm quality and fertilizing potential: The andrologist's viewpoint. Human Reproduction Update, 5, 393-398.

Comhaire, F., Verschraegen, G., \& Vermeulen, L. (1980). Diagnosis of accessory gland infection and its possible role in male infertility. International Journal of Andrology, 3, 32-45.

Corradi, G., Bucsek, M., Panovics, J., Verebelyi, A., Kardos, M., Kadar, A., \& Frang, D. (1996). Detection of Chlamydia trachomatis in the prostate by in-situ hybridization and by transmission electron microscopy. International Journal of Andrology, 19, 109-112.

Cosci, I., Moretti, E., \& Collodel, G. (2008). Lipid peroxidation in human spermatozoa from men with genitourinary infections. Systems Biology in Reproductive Medicine, 54, 75-83.

Da Ros, C. T., \& Da Silva Schmitt, C. (2008). Global epidemiology of sexually transmitted diseases. Asian Journal of Andrology, 10, 110-114.

De Geyter, C., De Geyter, M., Behre, H. M., Schneider, H. P., \& Nieschlag, E. (1994). Peroxidase-positive round cells and microorganisms in human semen together with antibiotic treatment adversely influence the outcome of in-vitro fertilization and embryo transfer. International Journal of Andrology, 17, 127-134.

Deguchi, T., \& Maeda, S. (2002). Mycoplasma genitalium: Another important pathogen of nongonococcal urethritis. Journal of Urology, 167, 1210-1217.

Dejucq, N., \& Jegou, B. (2001). Viruses in the mammalian male genital tract and their effects on the reproductive system. Microbiological and Molecular Biological Reviews, 65, 208-231.

Depuydt, C. E., Bosmans, E., Zalata, A., Schoonjans, F., \& Comhaire, F. H. (1996). The relation between reactive oxygen species and cytokines in andrological patients with or without male accessory gland infection. Journal of Andrology, 17, 699-707.

Diaz-Garcia, F. J., Herrera-Mendoza, A. P., Giono-Cerezo, S., \& GuerraInfante, F. M. (2006). Mycoplasma hominis attaches to and locates intracellularly in human spermatozoa. Human Reproduction, 21, 1591-1598.

Diemer, T., \& Desjardins, C. (1999). Disorders of spermatogenesis. In E. Knobil, \& J. D. Neill (Eds.), Encyclopedia of reproduction, (Vol. 4, pp. 546-556). San Diego, CA: Academic Press.

Diemer, T., Huwe, P., Ludwig, M., Schroeder-Printzen, I., Michelmann, H., Schiefer, H., \& Weidner, W. (2003). Influence of autogenous leucocytes and Escherichia coli on sperm motility parameters in vitro. Andrologia, 35, 100-105.

Diemer, T., Huwe, P., Michelmann, H., Mayer, F., Schiefer, H., \& Weidner, W. (2000). Escherichia coli-induced alterations of human spermatozoa. An electron microscopy analysis. International Journal of Andrology, 23, 178-186.

Diemer, T., Ludwig, M., Huwe, P., Hales, D. B., \& Weidner, W. (2000). Influence of urogenital infection on sperm function. Current Opinion in Urology, 10, 39-44.

Djordjevic, D., Lalic, N., Vukovic, I., Nale, D., \& Micic, S. (2018). Sperm quality and seminal biochemical parameters in infertile men with and without Leukocytospermia. Andrology, 7(2167-0250), 1000197. 
Dohle, G. R., Colpi, G. M., Hargreave, T. B., Papp, G. K., Jungwirth, A. Weidner, W. \& The EAU Working Group on Male Infertility (2005). EAU guidelines on male infertility. European Urology, 48, 703-711.

Domes, T., Lo, K. C., Grober, E. D., Mullen, J. B. M., Mazzulli, T., \& Jarvi, K. (2012). The incidence and effect of bacteriospermia and elevated seminal leukocytes on semen parameters. Fertility and Sterility, 97, 1050-1055.

Edwards, J. L., \& Apicella, M. A. (2004). The molecular mechanisms used by Neisseria gonorrhoeae to initiate infection differ between men and women. Clinical Microbiology Reviews, 17, 965-981.

el-Demiry, M. I.Hargreave, T. B., Busuttil, A., Elton, R., James, K., \& Chisholm, G. D. (1987). Immunocompetent cells in human testis in health and disease. Fertility and Sterility, 48, 470-479.

Eley, A., Hosseinzadeh, S., Hakimi, H., Geary, I., \& Pacey, A. A. (2005). Apoptosis of ejaculated human sperm is induced by co-incubation with Chlamydia trachomatis lipopolysaccharide. Human Reproduction, 20, 2601-2607.

Erenpreiss, J., Hlevicka, S., Zalkalns, J., \& Erenpreisa, J. (2002). Effect of leukocytospermia on sperm DNA integrity: A negative effect in abnormal semen samples. Journal of Andrology, 23, 717-723.

Esfandiari, N., Saleh, R. A., Abdoos, M., Rouzrokh, A., \& Nazemian, Z. (2002). Positive bacterial culture of semen from infertile men with asymptomatic leukocytospermia. International Journal of Fertility and Women's Medicine, 47, 265-270.

Esfandiari, N., Sharma, R. K., Saleh, R. A., Thomas, A. J., Jr., \& Agarwal, A. (2003). Utility of the nitroblue tetrazolium reduction test for assessment of reactive oxygen species production by seminal leukocytes and spermatozoa. Journal of Andrology, 24, 862-870.

Esterbauer, H. (1993). Cytotoxicity and genotoxicity of lipid-oxidation products. American Journal of Clinical Nutrition, 57(5 Suppl), 779S-786S.

Fariello, R. M., Del Giudice, P. T., Spaine, D. M., Fraietta, R., Bertolla, R. P., \& Cedenho, A. P. (2009). Effect of leukocytospermia and processing by discontinuous density gradient on sperm nuclear DNA fragmentation and mitochondrial activity. Journal of Assisted Reproduction and Genetics, 26, 151-157.

Fedder, J., \& Ellermann-Eriksen, S. (1995). Effect of Cytokines on sperm motility and ionophore-stimulated acrosome reaction. Archives of Andrology, 35, 173-185.

Fijak, M., Pilatz, A., Hedger, M. P., Nicolas, N., Bhushan, S., Michel, V., ... Meinhardt, A. (2018). Infectious, inflammatory and 'autoimmune' male factor infertility: How do rodent models inform clinical practice? Human Reproduction Update, 24, 416-441.

Fjällbrant, B., \& Obrant, O. (1968). Clinical and seminal findings in men with sperm antibodies. Acta Obstetricia Et Gynecologica Scandinavica, 47, 451-468.

Fraczek, M., Hryhorowicz, M., Gill, K., Zarzycka, M., Gaczarzewicz, D., Jedrzejczak, P., ... Kurpisz, M. (2016). The effect of bacteriospermia and leukocytospermia on conventional and nonconventional semen parameters in healthy young normozoospermic males. Journal of Reproductive Immunology, 118, 18-27.

Fraczek, M., \& Kurpisz, M. (2007). Inflammatory mediators exert toxic effects of oxidative stress on human spermatozoa. Journal of Andrology, $28,325-333$

Fraczek, M., \& Kurpisz, M. (2015). Mechanisms of the harmful effects of bacterial semen infection on ejaculated human spermatozoa: Potential inflammatory markers in semen. Folia Histochemica Et Cytobiologica, 53, 201-217.

Fraczek, M., Piasecka, M., Gaczarzewicz, D., Szumala-Kakol, A., Kazienko, A., Lenart, S., ... Kurpisz, M. (2012). Membrane stability and mitochondrial activity of human-ejaculated spermatozoa during in vitro experimental infection with Escherichia coli, Staphylococcus haemoIyticus and Bacteroides ureolyticus. Andrologia, 44, 315-329.

Fraczek, M., Sanocka, D., Kamieniczna, M., \& Kurpisz, M. (2008). Proinflammatory cytokines as an intermediate factor enhancing lipid sperm membrane peroxidation in in vitro conditions. Journal of Andrology, 29, 85-92.

Fraczek, M., Wiland, E., Piasecka, M., Boksa, M., Gaczarzewicz, D., Szumala-Kakol, A., ... Kurpisz, M. (2014). Fertilizing potential of ejaculated human spermatozoa during in vitro semen bacterial infection. Fertility and Sterility, 102, 711-719.

Francavilla, F., \& Barbonetti, A. (2017). Male autoimmune infertility. In W. Krause, \& R. Naz (Eds.), Immune Infertility: Impact of immune reactions on human fertility (2nd ed., pp. 187-196). Berlin, Heidelberg: Springer-Verlag.

Gallegos, G., Ramos, B., Santiso, R., Goyanes, V., Gosálvez, J., \& Fernández, J. L. (2008). Sperm DNA fragmentation in infertile men with genitourinary infection by Chlamydia trachomatis and Mycoplasma. Fertility and Sterility, 90, 328-334.

Gao, J., Wang, X., Wang, Y., Han, F., Cai, W., Zhao, B., ... Hu, D. (2016). Murine Sertoli cells promote the development of tolerogenic dendritic cells: A pivotal role of galectin-1. Immunology, 148, 253-265.

Gdoura, R., Kchaou, W., Chaari, C., Znazen, A., Keskes, L., Rebai, T., \& Hammami, A. (2007). Ureaplasma urealyticum, Ureaplasma parvum, Mycoplasma hominis and Mycoplasma genitalium infections and semen quality of infertile men. BMC Infectious Diseases, 7, 129.

Gomez, C. I., Stenback, W. A., James, A. N., Criswell, B. S., \& Williams, R. P. (1979). Attachment of Neisseria gonorrhoeae to human sperm. Microscopical study of trypsin and iron. British Journal of Venereal Diseases, 55, 245-255.

Gonzales, G. F., Munoz, G., Sanchez, R., Henkel, R., Gallegos-Avila, G., Diaz-Gutierrez, O., ... Bustos-Obregon, E. (2004). Update on the impact of Chlamydia trachomatis infection on male fertility. Andrologia, 36, 1-23.

González-Marín, C., Gosálvez, J., \& Roy, R. (2012). Types, causes, detection and repair of DNA fragmentation in animal and human sperm cells. International Journal of Molecular Sciences, 13, 14026-14052.

Grande, G., Milardi, D., Baroni, S., Luca, G., \& Pontecorvi, A. (2018). Identification of seminal markers of male accessory gland inflammation: From molecules to proteome. American Journal of Reproductive Immunology, 80, e12992.

Haidl, F., Haidl, G., Oltermann, I., \& Allam, J. P. (2015). Seminal parameters of chronic male genital inflammation are associated with disturbed sperm DNA integrity. Andrologia, 47, 464-469.

Haidl, G. (2002). Management strategies for male factor infertility. Drugs, 62, 1741-1753.

Haidl, G., Haidl, F., Allam, J. P., \& Schuppe, H. C. (2019). Therapeutic options in male genital tract inflammation. Andrologia, 51, e13207.

Harvey, H. A., Porat, N., Campbell, C. A., Jennings, M., Gibson, B. W., Phillips, N. J., ... Blake, M. S. (2000). Gonococcal lipooligosaccharide is a ligand for the asialoglycoprotein receptor on human sperm. Molecular Microbiology, 36, 1059-1070.

Hautamaki, R. D., Kobayash, D. K., Senior, R. M., \& Shapiro, S. D. (1997) Requirement for macrophage elastase for cigarette smoke-induced emphysema in mice. Science, 277, 2002-2004.

Head, J. R., Neaves, W. B., \& Billingham, R. E. (1983). Immune privilege in the testis. I. Basic parameters of allograft survival. Transplantation, 36, 423-431.

Hedger, M. P. (2011). Immunophysiology and pathology of inflammation in the testis and epididymis. Journal of Andrology, 32, 625-640.

Hedger, M. P., \& Winnall, W. R. (2012). Regulation of activin and inhibin in the adult testis and the evidence for functional roles in spermatogenesis and immunoregulation. Molecular and Cellular Endocrinology, 359, 30-42.

Hendry, W. F., Stedronska, J., Hughes, L., Cameron, K. M., \& Pugh, R. C. (1979). Steroid treatmenst of male subfertility caused by antisperm antibodies. Lancet, 2, 498-501.

Henkel, R. R. (2011). Leukocytes and oxidative stress: Dilemma for sperm function and male fertility. Asian Journal of Andrology, 13, 43-52. 
Henkel, R., Kierspel, E., Stalf, T., Mehnert, C., Menkveld, R., Tinneberg, H. R., ... Kruger, T. F. (2005). Effect of reactive oxygen species produced by spermatozoa and leukocytes on sperm functions in non-leukocytospermic patients. Fertility and Sterility, 83, 635-642.

Henkel, R., Maaß, G., Hajimohammad, M., Menkveld, R., Stalf, T., Villegas, J., ... Schill, W. B. (2003). Urogenital inflammation: Changes of leucocytes and ROS. Andrologia, 35, 309-313.

Henkel, R., Maaß, G., Jung, A., Haidl, G., Schill, W. B., \& Schuppe, H. C. (2007). Age-related changes in seminal polymorphonuclear elastase in men with asymptomatic inflammation of the genital tract. Asian Journal of Andrology, 9, 299-304.

Henkel, R., \& Schill, W. B. (1998). Sperm separation in patients with urogenital infections. Andrologia, 30, 91-97.

Homa, S. T., Vassiliou, A. M., Stone, J., Killeen, A. P., Dawkins, A., Xie, J., ... Ramsay, J. W. (2019). A comparison between two assays for measuring seminal oxidative stress and their relationship with sperm DNA fragmentation and semen parameters. Genes, 10, 236.

Hosseinzadeh, S., Brewis, I. A., Pacey, A. A., Moore, H. D., \& Eley, A. (2000). Coincubation of human spermatozoa with Chlamydia trachomatis in vitro causes increased tyrosine phosphorylation of sperm proteins. Infection and Immunity, 68, 4872-4876.

Hosseinzadeh, S., Pacey, A. A., \& Eley, A. (2003). Chlamydia trachomatis-induced death of human spermatozoa is caused primarily by lipopolysaccharide. Journal of Medical Microbiology, 52, 193-200.

Huwe, P., Diemer, T., Ludwig, M., Liu, J., Schiefer, H., \& Weidner, W. (1998). Influence of different uropathogenic microorganisms on human sperm motility parameters in an in vitro experiment. Andrologia, 30, 55-59.

Illiano, E., Trama, F., \& Costantini, E. (2020). Could COVID-19 have an impact on male fertility? Andrologia, 52, e13654. https://doi. org/10.1111/and.13654. [Online ahead of print]

Irvine, D. S. (1998). Epidemiology and aetiology of male infertility. Human Reproduction, 13(Suppl 1), 33-44.

Isaiah, I. N., Nche, B. T., Nwagu, I. G., \& Nnanna, I. I. (2011). Current studies on bacterospermia the leading cause of male infertility: A protégé and potential threat towards mans extinction. North American Journal of Medical Sciences, 3, 562-564.

Jung, J. H., Kim, M. H., Kim, J., Baik, S. K., Koh, S. B., Park, H. J., \& Seo, J. T. (2016). Treatment of leukocytospermia in male infertility: A systematic review. The World Journal of Men's Health, 34, 165-172.

Kaleli, S., Öçer, F., Irez, T., Budak, E., \& Aksu, M. F. (2000). Does leukocytospermia associate with poor semen parameters and sperm functions in male infertility? The role of different seminal leukocyte concentrations. European Journal of Obstetrics \& Gynecology and Reproductive Biology, 89, 185-191.

Kalugdan, T., Chan, P. J., Seraj, I. M., \& King, A. (1996). Polymerase chain reaction enzyme-linked immunosorbent assay detection of mycoplasma consensus gene in sperm with low oocyte penetration capacity. Fertility and Sterility, 66, 793-797.

Kapranos, N., Petrakou, E., Anastasiadou, C., \& Kotronias, D. (2003). Detection of herpes simplex virus, cytomegalovirus, and EpsteinBarr virus in the semen of men attending an infertility clinic. Fertility and Sterility, 79(Suppl 3), 1566-1570.

Karamolahi, S., Yazdi, R. S., Zangeneh, M., Makiani, M. J., Farhoodi, B., \& Gilani, M. A. S. (2019). Impact of hepatitis B virus and hepatitis C virus infection on sperm parameters of infertile men. International Journal of Reproductive Biomedicine (Yazd), 17, 551-556.

Kaur, G., Thompson, L. A., \& Dufour, J. M. (2014). Sertoli cellsImmunological sentinels of spermatogenesis. Seminars in Cell and Developmental Biology, 30, 36-44.

Kaur, K., \& Prabha, V. (2014). Spermagglutinating Escherichia coli and its role in infertility: In vivo study. Microbial Pathogenesis, 69, 33-38.

Keck, C., Gerber-Schäfer, C., Clad, A., Wilhelm, C., \& Breckwoldt, M. (1998). Seminal tract infections: Impact on male fertility and treatment options. Human Reproduction Update, 4, 891-903.
Kiessling, A. A., Lamparelli, N., Yin, H. Z., Seibel, M. M., \& Eyre, R. C. (1995). Semen leukocytes: Friends or foes? Fertility and Sterility, 64, 196-198.

Kjaergaard, N., Kristensen, B., Hansen, E. S., Farholt, S., Schonheyder, H. C., Uldbjerg, N., \& Madsen, H. (1997). Microbiology of semen specimens from males attending a fertility clinic. Acta Pathologica, Microbiologica, Et Immunologica Scandinavica, 105, 566-570.

Klein, B., Bhushan, S., Günther, S., Middendorff, R., Loveland, K. L., Hedger, M. P., \& Meinhardt, A. (2020). Differential tissue-specific damage caused by bacterial epididymo-orchitis in the mouse. Molecular Human Reproduction, 26, 215-227.

Kocak, I., Yenisey, C., Dündar, M., Okyay, P., \& Serter, M. (2002). Relationship between seminal plasma interleukin- 6 and tumor necrosis factor alpha levels with semen parameters in fertile and infertile men. Urological Research, 30, 263-267.

Köhn, F. M., Erdmann, I., Oeda, T., Mulla, K. E., Schiefer, H., \& Schill, W. B. (1998). Influence of urogenital infections on sperm functions. Andrologia, 30, 73-80.

Kokab, A., Akhondi, M. M., Sadeghi, M. R., Modarresi, M. H., Aarabi, M., Jennings, R., ... Eley, A. (2010). Raised inflammatory markers in semen from men with asymptomatic chlamydial infection. Journal of Andrology, 31, 114-120.

Koppers, A. J., Mitchell, L. A., Wang, P., Lin, M., \& Aitken, R. J. (2011). Phosphoinositide-3-kinase signaling pathway involvement in a truncated apoptotic cascade associated with motility loss and oxidative DNA damage in human spermatozoa. Biochemical Journal, 436, 687-698.

Kramer, M. D., Müller-Bardorff, M., Simon, M. M., Tilgen, W., Schickel, E., \& Petzoldt, D. (1990). Measurement of free human leukocyte elastase and human leukocyte elastase/alpha 1 proteinase inhibitor complexes by an enzyme-linked immunosorbent assay. Journal of Immunological Methods, 131, 41-48.

Kramer, M. D., Simon, M. M., Tilgen, W., Näher, H., Justus, C. W., \& Petzoldt, D. (1992). Alpha 2-macroglobulin and alpha 2-macroglobulin/proteinase complexes in human seminal fluid. Fertility and Sterility, 57, 417-421.

Krause, W. (2008). Male accessory gland infection. Andrologia, 40, 113-116.

Krausz, C. (2011). Male infertility: Pathogenesis and clinical diagnosis. Best Practice \& Research Clinical Endocrinology \& Metabolism, 25, 271-285.

Krieger, J. N., Nyberg, L., Jr., \& Nickel, J. C. (1999). NIH consensus definition and classification of prostatitis. JAMA, 282, 236-237.

Krieger, J. N., Ross, S. O., Deutsch, L., \& Riley, D. E. (2003). Seminal fluid analysis in chronic prostatitis/chronic pelvic pain syndrome. Andrologia, 35, 266-270.

Kumar, N., \& Singh, A. K. (2015). Trends of male factor infertility, an important cause of infertility: A review of literature. Journal of Human Reproductive Sciences, 8, 191-196.

Kung, A. W., Ho, P. C., \& Wang, C. (1993). Seminal leucocyte subpopulations and sperm function in fertile and infertile Chinese men. International Journal of Andrology, 16, 189-194.

La Vignera, S., Condorelli, R., D'Agata, R., Vicari, E., \& Calogero, A. E. (2012). Semen alterations and flow-citometry evaluation in patients with male accessory gland infections. Journal of Endocrinological Investigations, 35, 219-223.

La Vignera, S., Condorelli, R. A., Vicari, E., Salmeri, M., Morgia, G., Favilla, V., ... Calogero, A. E. (2014). Microbiological investigation in male infertility: A practical overview. Journal of Medical Microbiology, 63, 1-14.

La Vignera, S., Condorelli, R. A., Vicari, E., Tumino, D., Morgia, G., Favilla, V., ... Calogero, A. E. (2013). Markers of semen inflammation: Supplementary semen analysis? Journal of Reproductive Immunology, 100, 2-10.

Lackner, J. E., Agarwal, A., Mahfouz, R., Du Plessis, S. S., \& Schatzl, G. (2010). The association between leukocytes and sperm quality is 
concentration dependent. Reproductive Biology and Endocrinology, 8 , 12.

Lackner, J. E., Herwig, R., Schmidbauer, J., Schatzl, G., Kratzik, C., \& Marberger, M. (2006). Correlation of leukocytospermia with clinical infection and the positive effect of antiinflammatory treatment on semen quality. Fertility and Sterility, 86, 601-605.

Lang, T., Dechant, M., Sanchez, V., Wistuba, J., Boiani, M., Pilatz, A., ... Meinhardt, A. (2013). Structural and functional integrity of spermatozoa is compromised as a consequence of acute uropathogenic $E$. coli-associated epididymitis. Biology of Reproduction, 89, 59.

Le Tortorec, A., \& Dejucq-Rainsford, N. (2010). HIV infection of the male genital tract - Consequences for sexual transmission and reproduction. International Journal of Andrology, 33, e98-e108.

Leisegang, K., \& Henkel, R. (2018). The in vitro modulation of steroidogenesis by inflammatory cytokines and insulin in TM3 Leydig cells. Reproductive Biology and Endocrinology, 16, 26.

Leushuis, E., van der Steeg, J. W., Steures, P., Repping, S., Schöls, W., van der Veen, F., ... Hompes, P. G. A. (2009). Immunoglobulin G antisperm antibodies and prediction of spontaneous pregnancy. Fertility and Sterility, 92, 1659-1665.

Liu, J. H., Li, H. Y., Cao, Z. G., Duan, Y. F., Li, Y., \& Ye, Z. Q. (2002). Influence of several uropathogenic microorganisms on human sperm motility parameters in vitro. Asian Journal of Andrology, 4, 179-182.

Lobascio, A. M., De Felici, M., Anibaldi, M., Greco, P., Minasi, M. G., \& Greco, E. (2015). Involvement of seminal leukocytes, reactive oxygen species, and sperm mitochondrial membrane potential in the DNA damage of the human spermatozoa. Andrology, 3, 265-270.

Lopes, S., Jurisicova, A., Sun, J. G., \& Casper, R. F. (1998). Reactive oxygen species: Potential cause for DNA fragmentation in human spermatozoa. Human Reproduction, 13, 896-900.

Lopez-Plaza, I., \& Bostwick, D. G. (1990). Prostatitis. In D. G. Bostwick (Ed.), Pathology of the prostate (pp. 15-30). New York, NY: Churchill Livingstone.

Lotti, F., Baldi, E., Corona, G., Lombardo, F., Maseroli, E., Degl'Innocenti, S., ... Maggi, M. (2018). Epididymal more than testicular abnormalities are associated with the occurrence of antisperm antibodies as evaluated by the MAR test. Human Reproduction, 33, 1417-1429.

Lotti, F., \& Maggi, M. (2013). Interleukin 8 and the male genital tract. Journal of Reproductive Immunology, 100, 54-65.

Luczaj, W., \& Skrzydlewska, E. (2003). DNA damage caused by lipid peroxidation products. Cellular and Molecular Biology Letters, 8, 391-413.

Ludwig, M. (2008). Diagnosis and therapy of acute prostatitis, epididymitis and orchitis. Andrologia, 40, 76-80.

Ludwig, M., Vidal, A., Diemer, T., Pabst, W., Failing, K., \& Weidner, W. (2003). Chronic prostatitis/chronic pelvic pain syndrome): Seminal markers of inflammation. World Journal of Urology, 21, 82-85.

Lunenfeld, B., Van Steirteghem, A., \& Foundation, B. (2004). Infertility in the third millennium: Implications for the individual, family and society: Condensed meeting report from the Bertarelli Foundation's second global conference. Human Reproduction Update, 10, 317-326.

Maegawa, M., Kamada, M., Irahara, M., Yamamoto, S., Yamano, S., Ohmoto, Y., ... Aono, T. (2001). Concentration of granulocyte elastase in seminal plasma is not associated with sperm motility. Archives of Andrology, 47, 31-36.

Mahfouz, R., Sharma, R., Thiyagarajan, A., Kale, V., Gupta, S., Sabanegh, E., \& Agarwal, A. (2010). Semen characteristics and sperm DNA fragmentation in infertile men with low and high levels of seminal reactive oxygen species. Fertility and Sterility, 94, 2141-2146.

Marconi, M., Pilatz, A., Wagenlehner, F., Diemer, T., \& Weidner, W. (2009). Impact of infection on the secretory capacity of the male accessory glands. International Brazilian Journal of Urology, 35, 299-309.

Marconi, M., \& Weidner, W. (2017). Site and risk factors of antisperm antibodies production in the male population. In W. K. H. Krause, \& R.
K. Naz (Eds.), Immune infertility: Impact of immune reactions on human fertility (2nd ed., pp. 133-1147). Berlin, Heidelberg: Springer-Verlag.

Martinez, R., Proverbio, F., \& Camejo, M. I. (2007). Sperm lipid peroxidation and pro-inflammatory cytokines. Asian Journal of Andrology, 9, 102-107.

Mazzoli, S., Cai, T., Addonisio, P., Bechi, A., Mondaini, N., \& Bartoletti, R. (2010). Chlamydia trachomatis infection is related to poor semen quality in young prostatitis patients. European Urology, 57, 708-714.

McNaughton Collins, M., MacDonald, R., \& Wilt, T. J. (2000). Diagnosis and treatment of chronic abacterial prostatitis: A systematic review. Annals of Internal Medicine, 133, 367-381.

Mehta, R., Sridhar, H., Kumar, B. V., \& Kumar, T. A. (2002). High incidence of oligozoospermia and teratozoospermia in human semen infected with the aerobic bacterium Streptococcus faecalis. Reproductive Biomedicine Online, 5, 17-21.

Monga, M., \& Roberts, J. A. (1994). Sperm agglutination by bacteria: Receptor-specific interactions. Journal of Andrology, 15, 151-156.

Montag, M., van der Ven, H., \& Haidl, G. (1999). Recovery of ejaculated spermatozoa for intracytoplasmic sperm injection after anti-inflammatory treatment of an azoospermic patient with genital tract infection: A case report. Andrologia, 31, 179-181.

Moretti, E., Capitani, S., Figura, N., Pammolli, A., Federico, M. G., Giannerini, V., \& Collodel, G. (2009). The presence of bacteria species in semen and sperm quality. Journal of Assisted Reproduction and Genetics, 26, 47-56.

Moriyama, A., Shimoya, K., Kawamoto, A., Hashimoto, K., Ogata, I., Kunishige, I., ... Murata, Y. (1998). Secretory leukocyte protease inhibitor (SLP) concentrations in seminal plasma: SLPI restores sperm motility reduced by elastase. Molecular Human Reproduction, 4, 946-950.

Moskovtsev, S. I., Willis, J., White, J., \& Mullen, J. B. (2007). Leukocytospermia: Relationship to sperm deoxyribonucleic acid integrity in patients evaluated for male factor infertility. Fertility and Sterility, 88, 737-740.

Moskowitz, M. O., \& Mellinger, B. C. (1992). Sexually transmitted diseases and their relation to male infertility. Urologic Clinics of North America, 19, 35-45.

Moubasher, A., Sayed, H., Mosaad, E., Mahmoud, A., Farag, F., \& Taha, E. A. (2018). Impact of leukocytospermia on sperm dynamic motility parameters, DNA and chromosomal integrity. Central European Journal of Urology, 71, 470-475.

Muciaccia, B., Corallini, S., Vicini, E., Padula, F., Gandini, L., Liuzzi, G., ... Stefanini, M. (2007). HIV-1 viral DNA is present in ejaculated abnormal spermatozoa of seropositive subjects. Human Reproduction, 22, 2868-2878.

Muciaccia, B., Padula, F., Gandini, L., Lenzi, A., \& Stefanini, M. (2005). HIV-1 chemokine co-receptor CCR5 is expressed on the surface of human spermatozoa. AIDS, 19, 1424-1426.

Ness, R. B., Markovic, N., Carlson, C. L., \& Coughlin, M. T. (1997). Do men become infertile after having sexually transmitted urethritis? An epidemiologic examination. Fertility and Sterility, 68, 205-213.

Nickel, J. C. (1998). Prostatitis: Myths and realities. Urology, 51, 362-366.

Nickel, J. C., Downey, J., Hunter, D., \& Clark, J. (2001). Prevalence of prostatitis-like symptoms in a population based study using the National Institutes of Health chronic prostatitis symptom index. Journal of Urology, 165, 842-845.

Nieschlag, E., \& Behre, H. (1997). Andrology. Male reproductive health and dysfunction. Berlin, Germany: Springer.

Ochsendorf, F. (1999). Infections in the male genital tract and reactive oxygen species. Human Reproduction Update, 5, 399-420.

Ochsendorf, F. (2006). Urethritis, Sexually Transmitted Diseases (STD), Acquired Immunodeficiency Syndrome (AIDS). In W.-B. Schill, F. Comhaire, \& T. B. Hargreave (Eds.), Andrology for the clinician (pp. 327-338). Heidelberg, Germany: Springer. 
Osegbe, D. (1991). Testicular function after unilateral bacterial epididymo-orchitis. European Urology, 19, 204-208.

Pal, G. (2013). The effects of pegylated interferon-alpha2B on mumps orchitis. Journal of the Indian Medical Association, 111, 612-614.

Parks, J. E., \& Lynch, D. V. (1992). Lipid composition and thermotropic phase behavior of boar, bull, stallion, and rooster sperm membranes. Cryobiology, 29, 255-266.

Pasqualotto, F. F., Umezu, F. M., Salvador, M., Borges, E. Jr, Sobreiro, B. P., \& Pasqualotto, E. B. (2008). Effect of cigarette smoking on antioxidant levels and presence of leukocytospermia in infertile men: A prospective study. Fertility and Sterility, 90, 278-283.

Pellati, D., Mylonakis, I., Bertoloni, G., Fiore, C., Andrisani, A., Ambrosini, G., \& Armanini, D. (2008). Genital tract infections and infertility. European Journal of Obstetrics \& Gynecology and Reproductive Biology, 140, 3-11.

Pentyala, S., Lee, J., Annam, S., Alvarez, J., Veerraju, A., Yadlapalli, N., \& Khan, S. A. (2007). Current perspectives on pyospermia: A review. Asian Journal of Andrology, 9, 593-600.

Plante, M., de Lamirande, E., \& Gagnon, C. (1994). Reactive oxygen species released by activated neutrophils, but not by deficient spermatozoa, are sufficient to affect normal sperm motility. Fertility and Sterility, 62, 387-393.

Potts, J. M., Sharma, R., Pasqualotto, F., Nelson, D., Hall, G., \& Agarwal, A. (2000). Association of Ureaplasma urealyticum with abnormal reactive oxygen species levels and absence of leukocytospermia. Journal of Urology, 163, 1775-1778.

Potts, R., Notarianni, L., \& Jefferies, T. (2000). Seminal plasma reduces exogenous oxidative damage to human sperm, determined by the measurement of DNA strand breaks and lipid peroxidation. Mutation Research/Fundamental and Molecular Mechanisms of Mutagenesis, 447, 249-256.

Pratap, H., Hottigoudar, S. Y., Nichanahalli, K. S., Rajendran, S., \& Bheemanathi, H. S. (2019). Sperm DNA integrity in leukocytospermia and its association with seminal adenosine deaminase. Journal of Human Reproductive Sciences, 12, 182.

Punab, M., Lõivukene, K., Kermes, K., \& Mändar, R. (2003). The limit of leucocytospermia from the microbiological viewpoint. Andrologia, 35, 271-278.

Purvis, K., \& Christiansen, E. (1993). Infection in the male reproductive tract. Impact, diagnosis and treatment in relation to male infertility. International Journal of Andrology, 16, 1-13.

Ricci, G., Granzotto, M., Luppi, S., Giolo, E., Martinelli, M., Zito, G., \& Borelli, M. (2015). Effect of seminal leukocytes on in vitro fertilization and intracytoplasmic sperm injection outcomes. Fertility and Sterility, 104, 87-93.

Roberts, R. O., Lieber, M. M., Bostwick, D. G., \& Jacobsen, S. J. (1997). A review of clinical and pathological prostatitis syndromes. Urology, 49, 809-821.

Roberts, R. O., Lieber, M. M., Rhodes, T., Girman, C. J., Bostwick, D. G., \& Jacobsen, S. J. (1998). Prevalence of a physician-assigned diagnosis of prostatitis: The Olmsted County Study of Urinary Symptoms and Health Status Among Men. Urology, 51, 578-584.

Roessner, C., Paasch, U., Kratzsch, J., Glander, H. J., \& Grunewald, S. (2012). Sperm apoptosis signalling in diabetic men. Reproductive Biomedicine Online, 25, 292-299.

Rowe, P., Comhaire, F., Hargreave, T., \& Mellows, H. (1993). WHO manual for the standardized investigation and diagnosis of the infertile couple. Cambridge, UK: Press Synd Univ Cambridge.

Rumke, P. H. (1954). The presence of sperm antibodies in the serum of two patients with oligospermia. Vox Sanguinis, 4, 135-140.

Rutstein, S. O., \& Shah, I. H. (2004). Infecundity, infertility, and childlessness in developing countries. DHS Comparative Reports No. 9. Calverton, MD: ORC Macro and the World Health Organization.

Rybar, R., Prinosilova, P., Kopecka, V., Hlavicova, J., Veznik, Z., Zajicova, A., \& Rubes, J. (2012). The effect of bacterial contamination of semen on sperm chromatin integrity and standard semen parameters in men from infertile couples. Andrologia, 44, 410-418.

Said, T., Agarwal, A., Grunewald, S., Rasch, M., Baumann, T., Kriegel, C., ... Paasch, U. (2006). Selection of nonapoptotic spermatozoa as a new tool for enhancing assisted reproduction outcomes: An in vitro model. Biology of Reproduction, 74, 530-537.

Saleh, R. A., Agarwal, A., Kandirali, E., Sharma, R. K., Thomas, A. J. Jr, Nada, E. A., ... Alvarez, J. G. (2002). Leukocytospermia is associated with increased reactive oxygen species production by human spermatozoa. Fertility and Sterility, 78, 1215-1224.

Sanchez, R., Villagran, E., Concha, M., \& Cornejo, R. (1989). Ultrastructural analysis of the attachment sites of Escherichia coli to the human spermatozoon after in vitro migration through estrogenic cervical mucus. International Journal of Fertility, 34, 363-367.

Sandoval, J. S., Raburn, D., \& Muasher, S. (2013). Leukocytospermia: Overview of diagnosis, implications, and management of a controversial finding. Middle East Fertility Society Journal, 18, 129-134.

Sanocka-Maciejewska, D., Ciupińska, M., \& Kurpisz, M. (2005). Bacterial infection and semen quality. Journal of Reproductive Immunology, 67, $51-56$.

Santi, D., Spaggiari, G., \& Simoni, M. (2018). Sperm DNA fragmentation index as a promising predictive tool for male infertility diagnosis and treatment management - Meta-analyses. Reproductive Biomedicine Online, 37, 315-326.

Sasikumar, S., Dakshayani, D., \& Sarasa, D. (2013). An investigation of DNA fragmentation and morphological changes caused by bacteria and fungi in human spermatozoa. International Journal of Current Microbiology and Applied Sciences, 2, 84-96.

Saxena, P., Soni, R., Randhawa, V., \& Singh, N. (2019). Can seminal IL-8 level be used as a marker of leukocytospermia and does it have any correlation with semen parameters in infertile couples? The Journal of Obstetrics and Gynecology of India, 69, 451-456.

Schiefer, H. G. (1998). Microbiology of male urethroadnexitis: Diagnostic procedures and criteria for aetiologic classification. Andrologia, 30(Suppl 1), 7-13.

Schiefer, H. G., \& von Graevenitz, A. (2006). Clinical microbiology. In W.B. Schill, F. Comhaire, \& T. B. Hargreave (Eds.), Andrology for the clinician (pp. 401-407). Heidelberg, Germany: Springer.

Schulz, M., Sánchez, R., Soto, L., Risopatrón, J., \& Villegas, J. (2010). Effect of Escherichia coli and its soluble factors on mitochondrial membrane potential, phosphatidylserine translocation, viability, and motility of human spermatozoa. Fertility and Sterility, 94, 619-623.

Schuppe, H. C., \& Bergmann, M. (2013). Inflammatory conditions of the testis. In: Ježek D(ed.), Atlas on the Human Testis (pp 113-121), London: Springer Verlag.

Schuppe, H. C., \& Meinhardt, A. (2005). Immune privilege and inflammation of the testis. Chemical Immunology and Allergy, 88, 1-14.

Schuppe, H. C., Meinhardt, A., Allam, J. P., Bergmann, M., Weidner, W., \& Haidl, G. (2008). Chronic orchitis: A neglected cause of male infertility? Andrologia, 40, 84-91.

Schuppe, H. C., Pilatz, A., Hossain, H., Diemer, T., Wagenlehner, F., \& Weidner, W. (2017). Urogenital infection as a risk factor for male infertility. Deutsches Ärzteblatt International, 114, 339-346.

Schuppe, H. C., Pilatz, A., Hossain, H., Meinhardt, A., Bergmann, M., Haidl, G., \& Weidner, W. (2010). Orchitis and male infertility. Urologe A, 49, 629-635.

Sethi, S., Singh, G., Samanta, P., \& Sharma, M. (2012). Mycoplasma genitalium: An emerging sexually transmitted pathogen. Indian Journal of Medical Research, 136, 942-955.

Shahed, A. R., \& Shoskes, D. A. (2000). Oxidative stress in prostatic fluid of patients with chronic pelvic pain syndrome: Correlation with gram positive bacterial growth and treatment response. Journal of Andrology, 21, 669-675.

Sharma, R. K., Pasqualotto, F. F., Nelson, D. R., \& Agarwal, A. (2001). Relationship between seminal white blood cell counts and oxidative 
stress in men treated at an infertility clinic. Journal of Andrology, 22, 575-583.

Sharp, V. J., Takacs, E. B., \& Powell, C. R. (2010). Prostatitis: Diagnosis and treatment. American Family Physician, 82, 397-406.

Shukla, K. K., Mahdi, A. A., \& Rajender, S. (2012). Apoptosis, spermatogenesis and male infertility. Frontiers in Biosciences (Elite Ed), 4, 746-754.

Skau, P. A., \& Folstad, I. (2003). Do bacterial infections cause reduced ejaculate quality? A meta-analysis of antibiotic treatment of male infertility. Behavioral Ecology, 14, 40-47.

Solomon, M., \& Henkel, R. (2017). Semen culture and the assessment of genitourinary tract infections. Indian Journal of Urology, 33, 188-193.

Steiner, A. Z., Hansen, K. R., Barnhart, K. T., Cedars, M. I., Legro, R. S., Diamond, M. P., ...Reproductive Medicine Network. (2020). The effect of antioxidants on male factor infertility: the Males, Antioxidants, and Infertility (MOXI) randomized clinical trial. Fertility and Sterility, pii: S0015-0282(19)32547-6. 113: 552-560 https://doi.org/10.1016/j.fertnstert.2019.11.008

Stohl, E. A., Chan, Y. A., Hackett, K. T., Kohler, P. L., Dillard, J. P., \& Seifert, H. S. (2012). Neisseria gonorrhoeae virulence factor NG1686 is a bifunctional M23B family metallopeptidase that influences resistance to hydrogen peroxide and colony morphology. Journal of Biological Chemistry, 287, 11222-11233.

Sweeney, E. L., Dando, S. J., Kallapur, S. G., \& Knox, C. L. (2017). The human Ureaplasma species as causative agents of chorioamnionitis. Clinical and Microbiological Reviews, 30, 349-379.

Tanaka, K., Fujisawa, M., Arakawa, S., \& Kamidono, S. (1995). Local expression of cytokine messenger RNA in rat model of Escherichia coli epididymitis. Journal of Urology, 154, 2179-2184.

Taylor-Robinson, D. (2002). Mycoplasma genitalium - an up-date. International Journal of STD AIDS, 13, 145-151.

Tomlinson, M. J., Barratt, C. L. R., \& Cooke, I. D. (1993). Prospective study of leukocytes and leukocyte subpopulations in semen suggests they are not a cause of male infertility. Fertility and Sterility, 60, 1069-1075.

Tomlinson, M. J., White, A., Barratt, C. L., Bolton, A. E., \& Cooke, I. D. (1992). The removal of morphologically abnormal sperm forms by phagocytes: A positive role for seminal leukocytes? Human Reproduction, 7, 517-522.

Tremellen, K. (2008). Oxidative stress and male infertility-A clinical perspective. Human Reproduction Update, 14, 243-258.

Treulen, F., Uribe, P., Boguen, R., \& Villegas, J. V. (2015). Mitochondrial permeability transition increases reactive oxygen species production and induces DNA fragmentation in human spermatozoa. Human Reproduction, 30, 767-776.

Trum, J. W., Mol, B. W. J., Pannekoek, Y., Spanjaard, L., Wertheim, P., Bleker, O. P., \& van der Veen, F. (1998). Value of detecting leukocytospermia in the diagnosis of genital tract infection in subfertile men. Fertility and Sterility, 70, 315-319.

Turner, T. T., Mammen, T., Kavoussi, P., Lysiak, J. J., \& Costabile, R. A. (2011). Cytokine responses to E. coli-induced epididymitis in the rat: Blockade by vasectomy. Urology, 77, 1507.e9-14.

Twigg, J., Fulton, N., Gomez, E., Irvine, D. S., \& Aitken, R. J. (1998). Analysis of the impact of intracellular reactive oxygen species generation on the structural and functional integrity of human spermatozoa: Lipid peroxidation, DNA fragmentation and effectiveness of antioxidants. Human Reproduction, 13, 1429-1436.

Umapathy, E., Simbini, T., Chipata, T., \& Mbizvo, M. (2001). Sperm characteristics and accessory sex gland functions in HIV-infected men. Archives of Andrology, 46, 153-158.

Vallely, L. M., Egli-Gany, D., Pomat, W., Se Homer, C., Guy, R., Wand, H., ... Vallely, A. J. (2018). Adverse pregnancy and neonatal outcomes associated with Neisseria gonorrhoeae, Mycoplasma genitalium, M. hominis, Ureaplasma urealyticum and U. parvum: A Systematic review and meta-analysis protocol. British Medical Journal Open, 8, e024175.
Villegas, H., Pinon, M., Shor, V., \& Karchmer, S. (1991). Electron microscopy of Chlamydia trachomatis infection of the male genital tract. Archives of Andrology, 27, 117-126.

Villegas, J. V., Boguen, R., \& Uribe, P. (2017). Effect of Uropathogenic Escherichia coli on Human Sperm Function and Male Fertility. In: Samie A (ed.) Escherichia coli-Recent Advances on Physiology, Pathogenesis and Biotechnological Applications ( $\mathrm{pp}$ 71-80). IntechOpen.

Villegas, J., Schulz, M., Soto, L., Iglesias, T., Miska, W., \& Sánchez, R. (2005). Influence of reactive oxygen species produced by activated leukocytes at the level of apoptosis in mature human spermatozoa. Fertility and Sterility, 83, 808-810.

Villegas, J., Schulz, M., Soto, L., \& Sanchez, R. (2005). Bacteria induce expression of apoptosis in human spermatozoa. Apoptosis, 10, 105-110.

Wallach, E. E., \& Wolff, H. (1995). The biologic significance of white blood cells in semen. Fertility and Sterility, 63, 1143-1157. https://doi. org/10.1016/S0015-0282(16)57588-8

Wang, M., Fijak, M., Hossain, H., Markmann, M., Nüsing, R. M., Lochnit, G., ... Bhushan, S. (2017). Characterization of the micro-environment of the testis that shapes the phenotype and function of testicular macrophages. Journal of Immunology, 198, 4327-4340.

Wang, Y., Liang, C. L., Wu, J. Q., Xu, C., Qin, S. X., \& Gao, E. S. (2006). Do Ureaplasma urealyticum infections in the genital tract affect semen quality? Asian Journal of Andrology, 8, 562-568.

Weidner, W., \& Anderson, R. U. (2008). Evaluation of acute and chronic bacterial prostatitis and diagnostic management of chronic prostatitis/chronic pelvic pain syndrome with special reference to infection/ inflammation. International Journal of Antimicrobial Agents, 31(Suppl 1), S91-95.

Weidner, W., Colpi, G. M., Hargreave, T. B., Papp, G. K., Pomerol, J. M., Ghosh, C., ... EAU Working Group on Male Infertility (2002). EAU guidelines on male infertility. European Urology, 42, 313-322.

Weidner, W., Krause, W., \& Ludwig, M. (1999). Relevance of male accessory gland infection for subsequent fertility with special focus on prostatitis. Human Reproduction Update, 5, 421-432.

Weidner, W., Ludwig, M., Brähler, E., \& Schiefer, H. G. (1999). Outcome of antibiotic therapy with ciprofloxacin in chronic bacterial prostatitis. Drugs, 58(Suppl 2), 103-106. https://doi.org/10.2165/00003495199958002-00021

Weinberg, M., Sar-Shalom Nahshon, C., Feferkorn, I., \& Bornstein, J. (2020). Evaluation of human papilloma virus in semen as a risk factor for low sperm quality and poor in vitro fertilization outcomes: A systematic review and meta-analysis. Fertility and Sterility, 113, 955-969.

Wilson, L. (1954). Sperm agglutinins in human semen and blood. Proceedings of the Society of Experimental Biology and Medicine, 85, 652-655. https://doi.org/10.3181/00379727-85-20982

Witkin, S. S. (1988). Sperm-reactive antibodies as measured by enzyme linked immunosorbent assay. In S. Mathur, \& C. M. Fredricks (Eds.), Perspectives in immunoreproduction: Conception and contraception. Washington, DC: Hemisphere Publishing Company.

Witkin, S. S., \& Toth, A. (1983). Relationship between genital tract infections, sperm antibodies in seminal fluid, and infertility. Fertility and Sterility, 40, 805-808.

Wolff, H., Bezold, G., Zebhauser, M., \& Meurer, M. (1991). Impact of clinically silent inflammation on male genital tract organs as reflected by biochemical markers in semen. Journal of Andrology, 12, 331-334.

Wolff, H., Politch, J. A., Martinez, A., Haimovici, F., Hill, J. A., \& Anderson, D. J. (1990). Leukocytospermia is associated with poor semen quality. Fertility and Sterility, 53, 528-536.

World Health Organization (2010). WHO laboratory manual for the examination and processing of human semen (5th ed.). Geneva, Switzerland: WHO.

World Health Organization (2011). Global prevalence and incidence of selected curable sexually transmitted diseases: Overview and estimates. Geneva, Switzerland: WHO. 
Wright, J., Duchesne, C., Sabourin, S., Bissonnette, F., Benoit, J., \& Girard, Y. (1991). Psychosocial distress and infertility: Men and women respond differently. Fertility and Sterility, 55, 100-108.

Wu, H., Jiang, X., Gao, Y., Liu, W., Wang, F., Gong, M., ... Han, D. (2019). Mumps virus infection disrupts blood-testis barrier through the induction of TNF- $\alpha$ in Sertoli cells. FASEB Journal, 33, 12528-12540. https://doi.org/10.1096/fj.201901089R

Yang, J. J., Kettritz, R., Falk, R. J., Jennette, J. C., \& Gaido, M. L. (1996). Apoptosis of endothelial cells induced by the neutrophil serine proteases proteinase 3 and elastase. American Journal of Pathology, 149, 1617-1626.

Yeniyol, C. O., Sorguc, S., Minareci, S., \& Ayder, A. R. (2000). Role of interferon-alpha-2B in prevention of testicular atrophy with unilateral mumps orchitis. Urology, 55, 931-933.

Yoshida, T., Maeda, S., Deguchi, T., \& Ishiko, H. (2002). Phylogeny-based rapid identification of mycoplasmas and ureaplasmas from urethritis patients. Journal of Clinical Microbiology, 40, 105-110. https://doi. org/10.1128/JCM.40.1.105-110.2002

Zeighami, H., Peerayeh, S. N., Yazdi, R. S., \& Sorouri, R. (2009). Prevalence of Ureaplasma urealyticum and Ureaplasma parvum in semen of infertile and healthy men. International Journal of STD AIDS, 20, 387-390.

Zeyad, A., Amor, H., \& Hammadeh, M. E. (2017). The Impact of Bacterial Infections on Human Spermatozoa. International Journal of Womens Health and Reproduction Sciences, 5, 243-252. https://doi. org/10.15296/ijwhr.2017.43

Zhang, N., Wang, R., Li, X., Liu, X., Tang, Z., \& Liu, Y. (2014). Are Ureaplasma spp. a cause of nongonococcal urethritis? A systematic review and meta-analysis. PLoS One, 9, e113771.

Zhang, Z., Zhang, H., Dong, Y., Han, R., Dai, R., \& Liu, R. (2011). Ureaplasma urealyticum in male infertility in Jilin Province, North-east China, and its relationship with sperm morphology. Journal of International Medical Research, 39, 33-40.
Zhao, Y. T., Guo, J. H., Wu, Z. L., Xiong, Y., \& Zhou, W. L. (2008). Innate immune responses of epididymal epithelial cells to Staphylococcus aureus infection. Immunology Letters, 119, 84-90. https://doi. org/10.1016/j.imlet.2008.05.002

Zhou, J. F., Xiao, W. Q., Zheng, Y. C., Dong, J., \& Zhang, S. M. (2006). Increased oxidative stress and oxidative damage associated with chronic bacterial prostatitis. Asian Journal of Andrology, 8, 317-323. https://doi.org/10.1111/j.1745-7262.2006.00144.X

Zhou, Y. H., Ma, H. X., Shi, X. X., \& Liu, Y. (2018). Ureaplasma spp. in male infertility and its relationship with semen quality and seminal plasma components. Journal of Microbiology Immunology and Infection, 51, 778-783.

Zorn, B., Golob, B., Ihan, A., Kopitar, A., \& Kolbezen, M. (2012). Apoptotic sperm biomarkers and their correlation with conventional sperm parameters and male fertility potential. Journal of Assisted Reproduction and Genetetics, 29, 357-364. https://doi.org/10.1007/s1081 5-012-9718-x

Zorn, B., Vidmar, G., \& Meden-Vrtovec, H. (2003). Seminal reactive oxygen species as predictors of fertilization, embryo quality and pregnancy rates after conventional in vitro fertilization and intracytoplasmic sperm injection. International Journal of Andrology, 26, 279-285. https://doi.org/10.1046/j.1365-2605.2003.00424.x

Zorn, B., Virant-Klun, I., \& Meden-Vrtovec, H. (2000). Semen granulocyte elastase: Its relevance for the diagnosis and prognosis of silent genital tract inflammation. Human Reproduction, 15, 1978-1984. https:// doi.org/10.1093/humrep/15.9.1978

How to cite this article: Henkel R, Offor U, Fisher D. The role of infections and leukocytes in male infertility. Andrologia. 2021;53:e13743. https://doi.org/10.1111/and.13743 